\title{
Osmanlı Son Dönem Çeviri Yöntemleri Üzerine Bir İnceleme
}

\author{
Osman COȘKUN*
}

\begin{abstract}
Öz
Osmanlı tarihi kaynaklarında kurumsal olarak tercüme bahsi Fatih döneminde dek uzanan Divanı-1 Humayun Tercümanlığından tutun 11. Mahmut döneminde kurulan tercüme odasına kadar gider. Ardından ileriki dönemlerde bu odadan yetişenlerden ve çeviriyi meslek edinen kişilerden, diğer kurumsal yapılardan da bahsedilir. Önceki dönemlerde Arapça ve Farsça metinlerin tefsiri ile meali bağlamında çeviri ve izlenen yöntem üzerine yapılan çalışmalar vardır. Fakat özellikle batı dillerinden yapılan çeviri yöntemleriyle ile ilgili pek ayırt edici çalışmalara rastlanılmamaktadır. Bu çalışmada Osmanlı son döneminde çeviri geleneğimize 1şık tutabilecek bir örneği içerik ve çeviri yöntemi bağlamında ele almaya çalışacağız. Bunun için elimizde Tefeyyüz kitaphanesince yayınlanmış bulunan 1911 tarihli, "Français-Turc, Modèles de Traduction" çeviri kitabından hareketle şu soruya cevap arayacağız: Çeviri eğitimi için hazırlanan bu eserde nasıl bir içerik ve yöntem tercih edilmiştir? Ulaşılacak sonuçlarla tarihi mecrasında çeviri yöntemlerin gelişmesine 1şık tutacak veriler elde edilmesi düşünülmektedir. Eserin önsöz kısmı şu açıklamalardan ibarettir:

"En müntehab ahlakî parçalardan müteşekkil olan bu kitap Fransızcadan Türkçeye tercüme ile iştigal edenlerin teshil-i mesai ve tesri'-i muvafakiyetlerine medar olmak üzere kaleme alınmıştır. Binaenaleyh mekteb talebesiyle Fransızca tahsiline heveskâr olanlara güzel bir rehberdir. Esna-yı tercümede cümlelerin parlak, mustalah olmasından ziyade kelimatı mânâ-yı hakikîlerini ifadeye itina kılınmıştır. Bununla beraber şübban-ı vatanın hissiyat-ı millîyesini ikaz ve tenmiye etmek üzere mefahir-i milliyemizden bazı parçalar da ilave edilmiştir."
\end{abstract}

Yukarıda verilen bilgilerden eserin hangi amaçla hazırlandığı ve yöntemiyle ilgili önemli bilgiler elde edilmektedir. Buradan çevirmenlerin çağın gereklerine uygun olarak ne tür bir çeviri modelini tasvip ettikleri de ortaya konulmaktadir.

Anahtar Kelimeler: Çeviri, yöntem, çeviri tarihi, çeviribilim, diliçi/dillerarası.

\footnotetext{
* Dr. Öğr. Üy., Marmara Üniversitesi, Fen Edebiyat Fakültesi, Mütercim Tercümanlık Bölümü, İstanbul, Türkiye. Elmek: ocoskun77@gmail.com https://orcid.org/0000-0002-68033189
}

Geliş Tarihi / Received Date: 08.12.2019 Kabul Tarihi / Accepted Date: 20.02.2020

DOI: $10.30767 /$ diledeara.686650 


\title{
A Study on the Ottoman Last Period Translation Methodology
}

\begin{abstract}
In the Ottoman historical sources, the subject of institutional translation goes back from the Divan-i Humayun Interpreting which dates back to the period of Fatih to the translation room which was established during the period of II. Mahmut. Then, in the following periods it is mentioned about the people who grew up in this room and the people who took translation as a profession and other institutional structures. In the previous periods, there have been studies on translation and the method followed in the context of interpretation and translation of Arabic and Persian texts. However, there are not many distinctive studies on the methodology of translations especially from the Western languages. In this study, we will try to examine an example that may shed light on our translation tradition in the last period of Ottoman era in the context of translation method and its content. For this purpose, we will look for the answer to the following question with reference to the translation book "Fançais-Turc, Modèles de Traduction" published in 1911 by Tefeyyuz Library: What kind of a method and a content was preferred in this work prepared for translation education? With the results to be reached, it is thought to obtain data that will shed light on the development of translation methods in the historical medium. The preface of the work consists of the following explanations:

"Consisting of the most outstanding moral pieces, this book was written to facilitate the works of those who deal with French to Turkish translation and to help them accelerate their success. Besides, it is a good guide for students who wish to study French. At the time of translation, it was tried to give the exact meaning of words rather than bright and pompous sentences. In addition to this, some parts that we will be proud to stimulate and improve the national feelings of the youth of the homeland was also added."
\end{abstract}

The information above provides important information about the purpose and method of the work. Here, it is revealed what kind of translation model the translators approve in accordance with the requirements of the era.

Keywords: Translations, methodology, translation history, translation studies, intralangue/interlangue. 


\section{Extended Summary}

In the Ottoman historical sources, the subject of institutional translation goes back from the Divan-1 Hümayun (imperial council) interpreting, which dates back to the period of Fatih (Mehmed the Conqueror) the to the translation room which was established during the period of Mahmud II. Then, in the following periods it is mentioned about the people who grew up in this room and the people who took translation as a profession and other institutional structures. In the previous periods, there have been studies on translation and the method followed in the context of interpretation and translation of Arabic and Persian texts. However, there are not many distinctive studies on the methodology of translations especially from the Western languages. In this study, we will try to examine an example that may shed light on our translation tradition in the last period of Ottoman era in the context of translation method an its content. For this purpose, we will look for the answer to the following question with reference to the translation book "Fançais-Turc, Modèles de Traduction" published in 1911 by Tefeyyuz Library: What kind of a method and a content was preferred in this work prepared for translation education? With the results to be reached, it is thought to obtain data that will shed light on the development of translation methods in the historical medium. The preface of the work consists of the following explanations:

"Consisting of the most outstanding moral pieces, this book was written to facilitate the works of those who deal with French to Turkish translation and to help them accelerate their success. Besides, it is a good guide for students who wish to study French. At the time of translation, it was tried to give the exact meaning of words rather than bright and pompous sentences. In addition to this, some parts that we will be proud to stimulate and improve the national feelings of the youth of the homeland was also added."

The information above provides important information about the purpose and method of the work. Here, it is revealed what kind of translation model the translators approve in accordance with the requirements of the era. 
Kayaoğlu (1998: 22) approaches translation institutions in the Ottoman Empire under four headings: Divan-1 Hümayun (imperial council) translators; state translators; translators used in military and educational institutions in the 18 th century; foreign embassy and consular translators. It is known that teaching of French as a common foreign language was included in various institutions during the late Ottoman period. French was included in the curriculum of military schools and Ottoman junior high schools. While French teachers in military schools were providing education that influenced the mentality of the society, they were also writing pieces that would help them translate in a foreign language. Military schools were among the favorite educational institutions in those years as a result of the community's approach to education and exigence of necessities. It should be noted that the "masters" working in these institutions were usually composed of regulars.

The socio-cultural environment, the psychosocial situation and the economic structure in which the translator, the subject of translation, is shape the educational environment, and affect the source text, event, and case selection. During the translation studies education, sample texts are determined in line with the current translation needs and market demands. In this study, it has been tried to deal with diachronic intralingual translation applications together with the interlanguage (intralangue/interlangue) translation applications. The qualifications of the studies carried out in the late Ottoman Empire were revealed, and descriptive analyses were carried out in the context of translation practices, selected topics, content and methodology. Thus, it was tried to shed light on the translation history studies realized in the late Ottoman Empire.

Someone who wants to specialize in the field of translation in the Ottoman history will need to make use of such resources at the beginning level in order to reach the competence to transfer from Ottoman Turkish to French, English, German and to other languages. He will be required to read specialized texts, make a diachronic solution and then transfer to other languages. The handling of these texts in translation courses will contribute to candidate translators in determining the change and development of Turkish, French and other languages of study over time. In the late Ottoman Empire, existence of pragmatic 
texts and studies that include their translations for translation activities for junior schools (middle schools) and high schools was observed. It has been determined that these pragmatic texts contains content and terms that bear the traces of the period. It is designated that this content and terminology is concentrated in the military field in the discussed study. In addition, there are also cautionary translated texts containing the moral values of the period. In pragmatic text translations, which are the subject of the study, it is observed that generally oneto-one translation or expressions that will give the closest meaning are tried to be given as plain as possible. It is also likely to see examples given in contrary to this. In the contents, it was tried to provide diversity of types as well as richness of the subject. However, it is not possible to say that these are placed at an equal or balanced rate. 



\section{Giriş}

Osmanlı tarihi kaynaklarında kurumsal olarak tercüme bahsi, Fatih dönemine dek uzanan Divanı-1 Humayun Tercümanlığından, II. Mahmut döneminde kurulan tercüme odasına kadar gider. Sonraki dönemlerde buradan yetişenlerden ve çeviriyi meslek edinen kişilerden, diğer kurumsal yapılardan da bahsedilir. Fakat özellikle batı dillerinden yapılan çevirilerin yöntemleri ile ilgili pek ayırt edici çalışmalara rastlanmamaktadır. Ancak doğu dillerinden Arapça ve Farsçadan Dini metinlerin tefsiri ve ilerleyen dönemlerde meali bağlamında çevirileri ve buradaki yöntemler üzerine yapılan çalışmaları görmek mümkündür. Toplumların yaşantısı, gelenek görenekleri, bilim dünyasına katkıları, yaptıkları savaşlar ve bunların etkileri neden-sonuç bağlamında tarih biliminin temel konularından sadece birkaçıdır. Çeviribilimin çalışma konularından birisi olarak çeviri tarihi incelemelerinin de farklı konuları ele alması çok doğal bir olgudur. Bunlar, gerekli ve işlevsel çalışmalar olarak görülmelidir. Demircioğlu çalışmasında (2016: 20-98) uluslararası düzlemde çeviri tarihi ve yöntemi üzerine geliştirilen söylemlerden söz eder. Öncelikle çeviribilimin bağımsız bir disiplin haline gelmesinde önemli katkılarda bulunan André Lefèvre'den bahseder. Lefevère'nin tarih yazımını yeniden yazım etkinliği olarak gördüğünü belirtir. Hans Josef Vermeer’in çeviri tarihini ve tarih yazımını kültürlerarası iletişim ve yorumlama etkinliği bağlamında ele alıp çevirinin işlevsel boyutuna yoğunlaştığını belirtir. José Lambert'in çeviri tarihi çalışmalarına sistematik bir çerçevede yaklaşıp önemli katkı yaptığını vurgular. Kuramsal ve tarihsel artalan arasındaki yakın ilişki sorunsalını öncelediğini belirtir. Çeviri tarihinin konumuna ilişkin söylemlerde Susann Bassnett'in çeviri kuramları tarihine ilk yer veren çalışmalardan biri olduğuna değinerek bir disiplin olarak çeviri bilimin kendisine ait tarihsel bakış açısının olması gerektiğinin vurgular. Bassnett gibi çeviri tarihini araştırma konusu edinen diğer çeviribilimci Judith Woodsworth'un özellikle çevirmenlik mesleği ve çeviri eğitimi çerçevesinde çalışmalar yaptığına dikkat çeker. Öğrencilerin çeviri okullarında tarih ile kuramsal ve uygulamalı dersler arasında bağlantı kurmakta güçlük çektiklerini; 
bu sorunu aşmak için yayın çabalarının gelişmesinin önemini dile getirir. Georges L. Bastin'in ise çeviri tarihine postmodern bakış açısıyla yaklaştığını anlatır. $\mathrm{Bu}$ alana Avrupa ve Batı merkezli bakmanın sakıncalı olduğunu; Avrupalı yaklaşımla "Latin Amerika alt-kıtasının" tarihi artalanının betimlenemeyeceğini vurgular. Postmodern bakışla bu alana yaklaşan bilim çevrelerinden Paul F. Bandia'nın çeviri tarihi araştırmalarının bağımsız bir disiplin olması gerekliliğini dillendirir. İtalyan çeviribilimci Sergia Adamo'nun ise “çeviri tarihini marjinal ve müstakil bir mikro araştırma alanı" olarak gördüğüne değinir. James St. Andre'nin tarihsel bağlamda çevirinin kapsamı ve sınırlarını sorguladığını; bir metnin neye göre çeviri veya kimlerin çevirmen olarak kabul edilebileceği konularını ele aldığını belirtir. Şehnaz Tahir-Gürçağlar'ın çeviribilimin altında bir araştırma alanı olarak çeviri tarihini ele alıp Türkiye özelinde çeviri tarihine değinen araştırmacılardan biri olduğunu söyler. Gideon Toury'nin yöntem ve kavram bağlamında söylem geliştiren araştırmacılardan biri olarak, betimleyici çeviribilim tarihini ele ald1ğını belirtir. Onun betimleyici çeviri araştırmalarında kavramsal araçlar ortaya koyan ilk araştırmacılardan olduğundan söz eder. Antony Pym'in çeviri tarihinde yöntemi önceleyen çalışmalarıyla tanındığını öne çıkarır. Pym'in Method in Translation History (1998) adlı çalışmasında geçmiş çevirmenlerin ve geçmişte yapılan çevirilerin tarihi bağlamda ele alınmasına ilişkin yöntem geliştirme çabalarına değinir. Lieven D'hulst çeviri tarihi araştırmalarında çok-katmanlı ve çok-parametreli bir çalışma vurgusuna dikkat çeker. Japon çeviri tarihi üzerinde çalışan Judy Wakabayashi'nin tarih yazımını geçmişin bugüne yapılan bir “tercümesi” olarak tanımladığını aktarır. Lynne Long’un ise çeviri tarihini disiplinlerarası bir alan olarak betimleyip; yazınsal ve sosyal araştırmaları birbirine bağlayan bir alan olarak ele aldığını söyler. Martha P.Y. Cheung'un ise tui-shou(pushinghands) yaklaşımı ile geçmişle geleceği bağdaştırmaya uğraştığını belirtir.

Toplumların kültürel bağlamda dönüşümleri, bu dönüşümlerin onların politik yaşantılarına etkileri konusunda çeviribilimin özellikle farklı çağ ve işlevlerle klasik eserlerin çeşitli dil ve kültürlere aktarılması yoluyla önemli etkileri olduğu bilinmektedir. Bunun yanında çeviribilimcilerin çeviri artalanına ait verilere ihtiyaç duyma ve eğilme nedenleri farklılık gösterebilir. Bu bağlamda Anthony Pym çeviri tarihi araştırmanın nedenlerini şu şekilde ifade eder (Akt. Gülçağlar, 2005: 31); 
a- Farklı kültürlerin geçirdiği aşama ve dönüşümleri belirleme,

b- Geleceğe dönük politikaların oluşturulmasında tarihsel bilgi ve fikirlerden yeniden yararlanma,

c- Geçmişte çeviride ve kültürlerarası iletişimde rol almış bireylerin konumlarını ortaya çıkarma sayılabilir.

D’hulst (Akt. Demircioğlu, 2016: 73) ise çeviri araştırmalarının tarih alanına yönelimin nedenlerini şu şekilde açıklar;

1- Çeviri tarih alanı, çeviri araştırmaları için farkındalık yaratan elverişli bir alandir.

2- Yeni bakış açılarına yönelmek istendiğinde araştırmacıya entelektüel bir esneklik sağlar.

3- Araştırmacıyı sadece tek bir kurama körü körüne bağlanmaktan alıkoyar.

4- Farklı yaklaşım ve uygulamalar arasındaki temel ilişkileri göstererek disiplinin yapısını anlamamıza yardımcı olacak belki de tek araçtır.

5- "Bir çeviri kültürü"nün gelişmesine yardımcı olur.

6- Çeviri sorunlarını nasıl çözümleyeceğini düşünen çevirmenlere ilham verir.

Demircioğlu (2016: 38), Woodsworth'un çeviribilim alanında tarih yazımını yer, zaman, dil ve kültür toplulukları, çeviri türleri, metin türleri, çevirmenler, çeviri okulları, cinsiyet, kurumsal- ideolojik ve siyasi yapılar, kuram, uygulama, geniş coğrafi ya da kültürel birimler, yerel ve ulusal bakış açıları, özgün ve çeviri eserlerin dağılımları vb. birçok konu ve alt başlıklar şeklinde ele alınabileceğini belirtmiştir. Bu çerçevede eğitim kurumlarında çeviri uygulamaları ve yöntemlerinin de tarihi bağlamda ele alınması gereken bir alt başlık olarak değerlendirilmelidir.

Saliha Paker 1980'li yıllardan itibaren çoğul dizge ve betimleyici yaklaşım etkisinde Tanzimat döneminden başlayarak Türkiye'nin çeviri tarihini ele alır. Işın Bengi-Öner aynı bakış açısıyla Ahmet Mithat Efendi’nin Türk edebiyatında “La Dame aux Camélias” çevirilerini ele alır. Nedret Pınar (Kural) Faust çevirilerini inceler. Suat Karantay ve Berrin Aksoy tercüme bürosu konusunda çalışmalar yaptılar (Tahir-Gürçağlar, 2005: 29). Çeviri Tarihini betimleyici bir yaklaşımla 
ele alanlar arasında Şehnaz Tahir-Gürçağlar'ı da özellikle “Kapılar-Çeviri Tarihine Yaklaşımlar (2005)” adlı çalışmasıyla saymak gerekir. “Osmanlı Devleti'nde Tercümanlık ve Bab-ı ali Tercüme Odası (2006)" başlıklı tez çalışması ile Sezai Balcı bu konuda çalışma yapan diğer bir isimdir. Taceddin Kayaoğlu (1998) tercüme kurumlarını devlet eliyle kurulan tercüme heyetlerini, müesseselerini ve bunların üyelerini ele almaktadır. Bir tarihçi gözüyle ele alınan çalışma bu alanda dikkate değer niteliktedir.

Çevirinin akademik eğitim boyutu da kültürlerarası iletişimin olası stratejilerinden yalnızca biridir. Asıl alternatif kuşkusuz dil öğrenimi yani tüm sosyal grubun başka bir dili konuşması veya iki grubun ortak bir dil kullanmasıdır. Böylelikle dil öğrenimi çeviri yaptırmaya olan ihtiyacı ortadan kaldırabilir. Dil öğrenme başlangıçta çok büyük yük ve çaba gerektirir. Bu nedenle, bu strateji, ara sıra veya kısa vadeli işbirliğine dayalı ilişkiler için nadiren tercih edilir. Hiç kimse, bir hafta sürecek bir etkileşim için bütün bir dili öğrenmez. Kısa vadeli işbirlikleri için çeviri yaptırmak daha işlevsel olmaya devam etmektedir (Pym,1997:127).

Osmanlı son döneminde çeşitli kurumlarda yaygın bir yabancı dil olarak Fransızcanın eğitim öğretimine yer verildiği bilinmektedir. Askeri okul ve rüştiyelerin ders programlarında Fransızca dersi yer almaktadır. Askeri okullardaki Fransızca öğretmenleri bir yandan toplumun düşünce yapısına etki eden eğitim verirken diğer yandan yabancı dilde tercüme yapabilmelerine yardımcı olacak eserler yazıyorlardı. Askeri okullar o yıllarda toplumunun eğitime yaklaşımı ve ihtiyaçların gerekliliği neticesinde gözde eğitim kurumları arasındaydı. Bu kurumlarda görevli “muallimlerin” genellikle muvazzaf askerlerden oluştuğunu ifade etmek gerekir. Atatürk 24 Eylül 1924’te Samsun İstiklâl Ticaret Okulu'nda öğretmenler tarafından verilen çay ziyafetinde: “... Onların bize verdiği feyiz(bilim) elbette esersiz(sonuçsuz, ürünsüz) kalmamıştır. Şimdi burada bir zat-1 âliye (yüce, saygıdeğer bir kişiye) tesadüf ettim. O benim Rüştiye birinci sınıfında muallimim idi. Bana henüz iptidaî şeyler öğretirken istikbal(gelecek) için ilk fikirleri de vermişti..." (Akt. Akyüz, 1987: 71) Yukarıdaki satırlarda "istikbal için ilk fikirleri” kendisinden edindiğini ifade ettiği “zat-1 âli” Selanik’teki Askeri Rüştiye'den Fransızca öğretmeni Nakiyüddin Bey(Nakiyüddin Yücekök)'den başkası değildi. Çalışmaya konu eseri kaleme alanların da Fransızca öğretmenleri olduğunu belirt- 
mek gerekir. Bunlardan biri Mektebi Harbiye-i Şahane Lisan-1 Fransevi Muallimi Kolağası Mehmet Cemil Bey, diğeri Eyüb Rüştiye-i Askeriyyesi Lisan-1 Fransevi Muallimi Yüzbaşı Hüseyin Fehmi Bey’dir. Bu Fransızca öğretmenleri çeviri alanında uygulamalı eserlerde bir boşluk olduğunu düşünmüşler ve "Fransızcadan Türkçeye tercüme ile iştigal edenlerin" yararına bu çalışmayı hazırlamışlardır. Ayrıca bu çalışmanın öğrenciler ile Fransızca öğrenmek isteyenlere bir "rehber" niteliğinde olmasını arzu etmişlerdir.

\section{Tarihi Seyir}

Ârâmîce' de targmane/targem, İbrânîce'de targum, Asur dilinde targumanu biçimindeki ifade Arapça'a "trcm” kökünden türcümân/tercemân şeklinde bir dildeki ifadeleri başka bir dile aktaran kimse için kullanılır (Bozkurt, 2011: 489). Dilimizde önceleri farklı lehçelerde "dilmaç" olarak kullanılmakta olan sözcük günümüzde çevirmen olarak kullanılır. Sözlü çevirmen anlamına gelen "tercüman" sözcüğü XIII. Yy’dan itibaren, Fransızcada "drogman”, “drogeman”, “droguement"; İtalyancada, "dragomanno"; yunancada "dragoumanos" şeklinde kullan1la gelmiştir. Fransızcada levant ülkelerine gönderilen veya orada yerleşik bulunan elçiliklerdeki tercümanlara Drogman denilmekteydi. Fransa'da 1902 yılında drogman unvanı kaldırıldı (Le Grand Robert, Drogman maddesi). Fransızcada halen bu sözcükten türetilmiş “truchement” sözcüğü “aracı", "temsilci” anlamlarıyla "par le truchement de qqn/de qqc.” biri / bir şey aracılığıyla” yapısında kullanılmaktadır.

Yazıcı (2005: 47), Osmanlıda çeviri etkinliğinin bürokrasi, elçilikler, mühendislik, tıp okulları, tercüme büroları ve azınlık okulları olmak üzere beş alanda sürdürüldüğünü belirtir. Osmanlıda kurumsal yapıda tercümanlık kurumları da bulunmakta idi. Kayaoğlu (1998: 22) bu kurumları dört başlık altında ele alır. Bunlar; Divan-1 Hümayun tercümanları; eyalet tercümanlar1; XVIII. asırda askeri ve eğitim müesseselerinde kullanılan tercümanlar; yabancı elçilik ve konsolosluk tercümanlarıdır. Balcı (2006: 18-54) bu kurumları benzer bir bakışla; eyalet tercümanlığ1; donanma/derya tercümanlığı; yabancı elçi ve konsolosluk tercümanlı̆̆ı; Divan-1 Hümayun tercümanlığı şeklinde sınıflandırmıştır.

Tercümanlık XVIII. yüzyılda önemli bir meslek haline gelmiştir. Bunun nedeni askerlik ve toprak vergisinden tercümanların muaf tutulmasıdır. Ayrıca bu 
meslekte iş alanlarının geniş olması ve Divanı Hümayun tercümanlarının Eflak, Boğdan voyvodalıklarına kadar yükselebilmesi azınlık aileleri arasında kapışılıp tekelleşmesine yol açmıştır (Yazıcı, 2005: 49). Ayrıca bu yüzyılda artan uluslararası ilişkiler ve diplomasi tercüman ve tercümeye duyulan ihtiyacı arttırmıştır. Rum isyanıyla başlayan süreçte, kendilerine güvenin ortadan kalktığı Fenerli Rum ailelerinden divanı hümayun tercümanlığının alınması bu kurumun sonunu getirmiştir.

Balc1 (2006: 84) "23 Nisan 1821 tarihinde Yahya Naci Efendinin devlete gerekli olan tercüman ihtiyacını karşılamak üzere ders vermeye başlamasını Osmanlı Devletinde Tercüme Odası kuruluş tarihi olarak belirlemektedir. Yazıcı (2004: 90) ise, bu odanın resmi kuruluş tarihini 1833 olarak vermektedir. Bu tarihlerden sonra kurumsal yapılar olarak 1851-1862 yılları arasında Encümen-i Dâniş; 1861-1867 yılların arasında Cemiyyet-i İlmiyye-i Osmâniyye; 1865 yılında Telif ve Tercüme Dairesi; 1870 yılında Daire-i İlmiye ortaya çıkmıştır (Yazıcı, 2004: 122-131).

Osmanlıda yazılı kaynaklarda tercümanlardan ilk bahis Bartolomeo Langusco ile başlar. Langusco 1386'da I. Murad'ın Cenova Cumhuriyeti ile yapt1ğ1 antlaşmayı Türkçe'den Latinceye çeviren tercümandır. Cenovalı bir noterce hazırlanan 16 Temmuz 1414 tarihli, belgede "Sakız halkının Türkçe tercümanı olan Cristoforo Picenino, adı geçen sipahi Bayezid'in Türkçe emrini Latince'ye tercüme etti" ifadesinden bu kişinin Sakız halkına Türkçe tercümanlık yaptığı anlaşılmaktadır. İstanbul'un fethinden sonra Galata'nın anahtarını Fâtih Sultan Mehmed'e sunan Cenova heyetinde, Nicolo Pagliuzzi adında Türkçe bilen bir tercüman bulunuyordu. Öncesinde bu görevde S. Parrisola adında bir tercüman bulunduğu bilinmektedir. Nicolo bu makamı 5 Haziran 1449'da selefi S. Parrisola'dan devralmıştı. 6 Temmuz 1454'te Ulûfecibaşı Ahmed ile Demetrios Grisovergi [Tercümanlık yapan kişi olsa gerek] adlı kişi Venedik Cumhuriyeti idarecileri tarafından kabul edilmiştir. 1463’te Uzun Hasan'ın Venedik ile işbirliği yapacağını öğrenen Osmanlı yöneticileri bu duruma karşı bir adım olarak Nicolo Corner adlı bir tercümanı beraberinde bir elçiyle Milano Dukalığıyla iş birliği için Milanoya yollamıştır. 1463-1479 yılları arasında devam eden Osmanlı-Venedik savaşı sonunda Venedik şehrinde Giovanni Dario isimli, itibar sahibi bir 
kişinin yetiştiği ve Türk elçileriyle yakın temas kurduğu anlaşılmaktadır. 1479 antlaşmasının metnini Venedik devlet başkanına sunan Lutfi adındaki bu zatın büyük merasimle karşılandığı, maiyetinde bulunan kişilerin iyi ağırlandığı ve bu tarihten sonra temsilcinin “büyük Türk’ün elçisi” diye anıldığı çağdaş kroniklerde söz edilir. Emanuele adlı bir tercümanın 1481 Mayıs ayı sonunda Fâtih Sultan Mehmed'in vefat ettiği haberini Venedik'e ulaştırdığından bahsedilir (Şakiroğlu, 2011: 491). Devlet tercümanlarının, adları ve dragoman ünvanının kaydedilmesi II. Bayezid dönemine rastlar. Ağustos 1503 tarihinde defterdarlık personeli için "Şakirdan-1 Katibân-1 Hazine-i Amire" başlığı altında "dragoman" ünvanıyla Alaaddin, İskender ve İbrahim adlı üç tercüman kaydedilmiştir. İnamat defterinde bazı kayıtlara göre ilk “baştercüman” ünvanını alan Ali Bey’in adı ilk kez 11 Ocak 1507 tarihli bir listede geçmiş olup, onun 1502 yılında tercüman olarak görev yaptığı da bilinmektedir (Aydın, 2007: 45-46). Osmanlı sarayında Kanuni'nin Rum asıllı dragomanı, baştercümanı Yunus Ağa eski adıyla Josef Matuz dönemin en tanınmış tercümanıydı. Bu görevi çeyrek asırdan fazla sürdürmüştür (Bacqué-Grammont, 1997: 23). Yunus Ağa tercüman olmadan öte Osmanl1-Venedik ilişkilerinde üstlendiği diplomatik görevler dolayısıyla dönemin Osmanlı diplomasisinin önemli figürlerindendir (Aydın, 2007: 46). Mimar Sinan’a İstanbul Fatih-Balat civarı Draman Yokuşunda bulunan Dragman Camii'ni yaptırmıştır. Cami adını Yunus Ağanın lakabından alır. Yunus Ağa’nın Venedik Doç'unun gayrı meşru oğlu Alviso Giritti ile Osmanlı Devlet idaresi üzerine önemli bir araştırması basılmıştır (Güran, 2007:231). Yunus Bey’den sonra Divan tercümanlığında Viyanalı, Müslüman olduktan sonra Ahmed ismini almış olan Heinz Tulman görevlendirilmiş idi. Tercüman Ahmed'den sonra Divan tercümanlığında Murat ad1na rastlanmaktadır. Erdel'li bir Hristiyan olan Murat, Macar tercümanlardandır. Macarca isminin Balazs Somlyai olduğu bilinir. XVI. Yüzyılda görev almış ünlü tercümanlardan biri de Polonyalı Joachim Strasz'dır. müslüman olduktan sonra İbrahim ismini alan Joachim 1550〉de baştercümanlık görevine tayin edilmiştir. Divan-1 Hümayun baş tercümanlarından Mahmud Bavyeralı bir albay iken Osmanlı Devleti hizmetine girerek müslüman olmuştur. Hakkında fazla bilgi olmayan tercüman Oram (1573) ve Hürrem Bey'den (1578) sonra adına çeşitli arşiv belgelerinde tesadüf ettiğimiz bir diğer tercüman da Mustafa'dır. Mustafa'dan 
sonra bu göreve Macar asıllı tercüman Zülfikar getirilmiştir. Zülfikar Efendi’nin yerine $1657^{\prime}$ de Panayoti Nikusius'un tayiniyle Osmanlı divan tercümanlığında Rum dragomanlar dönemi başlamıştır. Panayoti, imparatorluğun dış siyasetinde görevlendirilmiş ilk Rum'dur. Osmanlı Devlet adamlarının güvenini kazanan Fenerli aileler birkaç nesil boyunca Divan tercümanlığını yürütmüştü. Bu tercüman ailelerinin en önemlilerinden biri İskerletzadelerdi. XVIII. Yüzyıl ortalarına kadar Osmanlı Devleti'ne pek çok tercüman yetiştirmiş bu aile, büyük bir nüfuza sahip olmuştu. 1821 yılında patlak veren Yunan isyanları, Rum tercüman çalıştırmadaki olumsuz durumu acı bir şekilde ortaya koydu. İsyandaki rolü ve ihaneti sebebiyle tercüman Constantine Mourouzi'nin 16 Nisan 1821 'de idam edildi. Böylelikle Fener'li tercümanlar dönemi son buldu (Aydın, 2007: 54-60)

III. Ahmed devrinde, 1717 'de Sadrazam Nevşehirli Damat İbrahim Paşa yirmi beş kişiden oluşan bir tercüme heyeti oluşturmuştur. Bu batıya doğru ilk adım ve açılımın başlangıcıdır (Budak, 2013: 39). Bu devirde Yanyalı Esad Efendi, Heratlı Kābızî Efendi, Mansûrîzâde müderris Fasîhî Efendi, İshak Efendi, Şam kad1s1 Medhî Efendi, Halep kadısı İlmî Efendi, Selânik kadısı Müstecirzâde Abdullah Efendi, Kara Halilzâde Mehmed Said Efendi ve şair Nedîm gibi ilim, fikir ve edebiyat adamlarından kurulu tercüme heyeti sürekli toplanıp, Doğu ve Batı dillerindeki eserlerden tercümeler yapıyordu. Fransızca'dan bazı eserler ilk defa bu devirde Türkçe'ye çevrildiği gibi Türkçe'den Fransızca'ya tercüme edilerek basılan edebî kitaplar da vardır (Aktepe, 1989: 37). Yanyalı Esad Efendi, Aristo'nun Fizika'sını Klasik Yunancadan Arapçaya çevirmiş, Esad Efendi bu çevirisi ile ögüunmüştür. Çünkü eski tercümeler Yunancadan Süryaniceye oradan da Arapçaya tercüme edilirdi. Fakat Esad Efendi'nin tercümesi bir işe yaramadi; çünkü milattan 350 sene önce yazılmış bir fizik kitabının XVII. asırda hiçbir işlevi olamazdı. Ama bir arayış vard1. III. Ahmet, 1724'te Spatroti adlı Rum'a Aristo'nun eserlerini çevirmesi, bunun karşılığında ondan ve cariyelerinden dahi vergi alınmamasını isteyen bir ferman çıkarmıştı. Bu fermanı padişah, 1743'te yeniledi (Bolay, 2002: 516). XVIII. yüzyılda, mühendislik okulları açılmış, teknik eserler Türkçeye çevrilmiş, bazı kurumlarda öğretim çeviri aracılığıyla gerçekleştirilmiştir (Yalçın, 2015: 25).

Ülken(2016:232) XVIII. yüzyılda Nahîfî tarafından yapılan Mevlana’nın Mesnevisinin bir tercümesi “Terceme-i Mesnevî li-Nahîf̂”’yi “Osmanlı tercü- 
me devrinin en mühim tercüme hadiselerinden biri” olarak görür. Bu eser Şair Nahîfî'nin en önemli çalışması olup Meșnevî’nin tamamının manzum bir Türkçe çevirisidir. Eser Farsça aslı ile birlikte yedi cilt halinde basılmıştır (Uzun, 2006:298).

\section{Tanzimat Döneminde Batı Edebiyatından İlk Çeviriler}

Tanzimatla birlikte, batılılaşma sürecine girecek olan Osmanlı toplumundaki kültürel dönüşümde çevirinin önemli bir rolü olmuştur (Yalçın, 2015: 25). Bu döneme kadar Osmanlıda genellikle Arapça ve Farsçadan en fazla tasavvuf, kelam ve mantık alanında çeviriler yapılmaktaydı (Ülken, 2016:232). Batı edebiyatından roman, hikâye ve şiir türünden ilk çeviriler 1850'lerin sonlarında yapılmıştır. Kültürlü ve seçkin bir devlet adamı olan, Arapça, Farsça ve Fransızca bilen Yusuf Kâmil Paşa, François de Salignac de la Mothe-Fénelon'un Les aventures de Télémaque adlı eserini Türkçe'ye çevirerek Tercüme-i Telemak adıyla 1862'de yayımlamıştır. Bu kitap 1863, 1870, 1877 ve 1881'de tekrar basılmıştır. Bu tercüme süslü ve secili ağır diliyle bir inşâ örneği sayılır (Beyoğlu, 2001:284). Ahmet (Mehmet) Münif Efendi Muhâverât-ı Hikemîye'sinde Fénelon, Fontainelle ve Voltaire'in felsefi konuşmalarından seçtiği metinlerin tercümesini yapmış; İbrahim Şinasi Tercüme- $i$ Manzume adlı eserinde Lamartine, Musset, Hugo ve Racine'den "çoğu münferit mısra ve beyitlerle" şiir çevirilerinin yanında Racine, Lamartine, La Fontaine, Gilbert ve Fénelon'dan parçalar tercüme etmiştir (Tanpınar, 2018: 157). Daha sonraları 1868'de Memduh Paşa, Alphonse de Lamartine'nin Geneviève adlı eserini Hikâye-i Jöneviyev adiyla tercüme etmiştir. Bu çevirilerin hepsinin ortak noktası Fransızca dilinden Osmanlıcaya yapılmasıdır.

Baysal 1729-1875 yılları arasında kayıt altına alınabilmiş/ulaşılmış eserlerle ilgili çalışmasında çeviri eserlerle ilgili Fransızcadan 109, İngilizceden 13, Almancadan 9, İtalyancadan 4, Latinceden 3, Slav dillerinden 3, Yunancadan 3 eser çevrilmiş olduğunu; hangi dilden çevrildiği bilinmeyen 41 eser mevcut olduğunu belirtmektedir (Baysal, 2010: 48).

Osmanlı'daki ilk çeviri eleştirisi olarak nitelendirilebilecek çalışmayı Kemalpaşazade Said Bey yapmış ve Fransızcadan yapılmış çevirilere ilişkin görüş ve önerilerini,1889'dan başlayarak 18 defter halinde yayımladığı Galatât-ı Tercüme 
adlı risalesinde ortaya koymuştur. Böylece oluşan tartışma ortamında, önce Fransızca öğretmeni Mehmed Halit Bey Tetkîk-i Galatât-ı Tercüme, ardından da gazeteci Fatin İhsan Bey Hatiyât-ı Tercüme adlı risalelerini yayımlayarak Kemalpaşazade Said Bey’in eleştirisinin eleştirisini yapmışlardır (Semercioğlu, 2010: 29).

\section{1828-1911 Yılları Arasında Basılan Çeşitli Sözlükler}

$\mathrm{Bu}$ başlıkla çevirmenin vazgeçilmezi olan o dönemin sözlüklerine k1sacık da olsa değinmek gerekmektedir. Aşağıda not edilen iki veya çok dilli sözlükler dönemin nasıl yoğun bir kültürel faaliyetle geçirildiğinin en önemli göstergelerinden biri olarak görülebilir. Çeviri faaliyetlerinin artmasıyla eşzamanlı olarak bu kadar hacimli sözlüklerin ortaya konulması da ilgi çekicidir. 1828-1911 y1lları arasında basılanların kısmi bir özeti halinde adını verdiğimiz bu sözlüklerin sadece bir seçki olduğunun; bu dönemde kaleme alınanların tümünün listesi olmadığının altını çizmek gerekir.

Rhasis 1828' de “Vocabulaire Français-Turc, L'imprimerie de l'Académie Impériale des Sciences” adlı çalışmayı yayınlamıştır. Bu sözlük Petersburg'da basılmıştır. Hindoglu 1831 yılında “ Dictionnaire Abrégé Français-Turc” adlı çalışmayı yayınlamıştır. Bu çalışma Viyana'da basılmıştır. Thomas Xavier Bianchi, 1831 'de "'Vocabulaire Français-Turc à l'Usage des Interprètes, des Commerçans, des Navigateurs, et Autres Voyageurs dans le Levant” adlı çalışmayı hazırlamıștır. Bu kitap Paris'te basılmıştır. Aucher 1840’ta “Dictionnaire Français-ArménienTurc” adlı sözlüğü yayınlamıştır. Bu sözlük Venedik’te basılmıştır. Alexandre Hançeri 1841 'de "Dictionnaire Français-Arabe-Persan et Turc Enrichi d'Exemples en Langue Turque avec des Variantes, et de Beaucoup de Mots d'Arts et de Sciences" başlıklı sözlüğü yayınlamıştır. Çalışma dört dilli olması nedeniyle dikkat çekicidir. Bu çalışma Moskovada basılmıştır. Bianchi'nin diğer eseri 1843 'te yayınladığ "Dictionnaire Français-Turc à l>Usage des Agents Diplomatiques et Consulaires, des Commerçants, des Navigateurs et Autres Voyageurs dans le Levant"”dır. Pariste basılmıştır. Nassif Mallouf 1856'da "Dictionnaire Français-Turc, avec la Prononciation Figurée” adlı sözlüğü yayınlamıştır. Bu eser Paris’te basılmıştır. James W. Redhouse 1856'da "English and Turkish Dictionary” adlı sözlüğü yayınlamıştır. Bu sözlük Londra'da basılmıştır. Jules Théodore Zenker 1866-1876 yılları arasında 
“Dictionnaire Turc-Arabe-Persan” adlı Türkçe-Arapça ve Farsça üç dilli bir sözlük çalı̧ması olarak yayınlamıştır. Eser Leipzig'de basılmıştır. Wssehrd 1870'de " $M a$ nuel Terminologique Français-Ottoman" adlı çalı̧̧ayı Viyana'da yayınlamıştır. Şemseddin Sami 1883'de "Dictionnaire Turc-Français" adlı sözlüğü yayınlamıştır. Bu sözlük İstanbul'da basılmıştır. R. Youssouf 1890 'da "Dictionnaire portatif Turc-Français de le Langue Usuelle en Caractères Latins et Turcs" adlı sözlüğü İstanbul'da yayınlamıştır. Nazıma 1910'da "Dictionnaire Tefeyuz Ottoman-Français à l'Usage des Ecoles Sultanié et Idadié” adlı sözlüğü hazırlamıştır. Bu çalışma İstanbul'da basıllmıştır. Kelekyan 1911'de "Dictionnaire Turc-Français (Kâmus-l Fransavî)" adlı sözlüğü yayınlamıştır. Bu çalışma İstanbul'da basılmıştır. Görülüyor ki bu çalışmalar yoğunlukla Osmanlı toprakları dışında yayınlanmıştır. $\mathrm{Bu}$ bakımdan ayrıca araştırmaya değer bir başlıktır.

\section{Eser: Modèles de Traduction}

Bu çalışmada Osmanlı son döneminde çeviri geleneğimize 1şık tutabilecek 1911 yılına ait bir çalışmayı artsüremli ve dillerarası çeviri çerçevesinde içerik ve seçilen yöntemi bakımından betimleyici bir bakışla ele almaya çalışacağız. Çevirinin bütün alanlarını kuşatan bir kavram olarak çeviri eğitimi (Eruz,2008: 53), bu çerçevede önceden kullanılmış yayınların içeriğine de yer verir. "Tefeyyüz kitaphanesince" yayınlanmış bulunan "Fançais-Turc/Turc-Français, Modèles de Traduction" (Bkz. Ek 1 ve Ek 2) kitabından hareketle şu soruya cevap arayacağız: Çeviri eğitimi için ne tür içerikler seçilmiştir? İçerik ve dönemin özellikleri arasında nasıl bir bağ kurulabilir? Özel bir çeviri yöntemi tercih edilmiş midir? Ulaşılacak sonuçlarla tarihi mecrasında çeviribilime küçük de olsa 1şık tutacak veriler elde edilmesi umulmaktadır. Öncelikle eserin önsözüne bir göz atalım.

"En müntehab ahlakî parçalardan müteşekkil olan bu kitap Fransızcadan Türkçeye tercüme ile iştigal edenlerin teshil-i mesai ve tesri'-i muvafakiyetlerine medar olmak üzere kaleme alınmıştır. Binaenaleyh mekteb talebesiyle Fransızca tahsiline heveskâr olanlara güzel bir rehberdir. Esna-yl tercümede cümlelerin parlak, mustalah olmasından ziyade kelimatı mânâ-yı hakikîlerini ifadeye itina kılınmıştır. Bununla beraber şübban-ı vatanın hissiyat-ı millîyesini ikaz ve tenmiye etmek üzere mefahir-i milliyemizden bazı parçalar da ilave edilmiştir." 
Kitabın önsözünde verilen bilgilerden eserin ne amaçla hazırlandığı ve yöntemi ile ilgili önemli çıkarımlar yapılabilir. «Esna-yı tercümede cümlelerin parlak, mustalah olmasından ziyade kelimatı mânâ-yı hakikîlerini ifadeye itina kılınmıştır.» $\mathrm{Bu}$ satırlarda yazarlar serbest bir çeviri yerine sözcüklerin gerçek anlamlarından yola çıkarak birebir bir çeviri ortaya koyma isteğinde oldukları söylenebilir.

\subsection{Modèles de Traduction Adlı Eserde Geçen Kullanmalık Metinler}

Kullanmalık metinler ders içi çalışmaların çeviri edincinde öğrencilerin dil ve kültür yönünden gelişimlerine katkı sağlar. "Çeviri amaçlı metin çözümleme dersinde uygulama örnekleri çoğunlukla kullanmalık metinlerden seçilir. Ancak zaman zaman uzmanlık metinleri ve yazınsal metinlerin de çeviri amaçlı çözümlenmesi gerekmektedir (Esen-Eruz, 2008: 74). Eserde geçen kullanmalık metinler şunlardır:

\begin{tabular}{|l|}
\hline 1. Orgueilleuse $\sim$ Mütekebbire \\
\hline 2. Les nids d'oiseaux-Kuş yuvaları \\
\hline 3. Perspicacité d'un İndien $\sim$ Bir hintlinin fetaneti \\
\hline 4. La vigne $\sim$ Bağ \\
\hline 5. L'enfant et l'aveugle $\sim$ Çocuk ve ama \\
\hline 6. La poule $\sim$ Tavuk \\
\hline 7. Un bédouin affamé $\sim$ Aç kalmış bir bedevi \\
\hline 8. Le champ $\sim$ Tarla \\
\hline 9. Les trois brigands $\sim$ Üç haydut \\
\hline 10. Jugement remarquable d'un juge $\sim$ Bir hâkimin şayana deger bir hükmü \\
\hline 11. Le chien intelligent et fidele $\sim$ Zeki ve sadık bir köpek \\
\hline 12. La pluie $\sim$ Yağmur \\
\hline 13. La source $\sim$ Menbağ \\
\hline 14. Le loup Kurt \\
\hline 15. Le singe $\sim$ Maymun \\
\hline 16. Le pain $\sim$ Ekmek \\
\hline 17. Osman Pacha et sa vie militaire $\sim$ Osman Paşa ve hayat-1 askeriyesi \\
\hline 18. La lettre du grand-duc Nicolas à Osman Pacha défenseur héroique de Plevna $\sim$ Gran dük \\
Nikola tarafindan Plevne Kahramanı Osman Paşa'ya yazılan mektubu \\
\hline 19. La réponse d'Osman Pacha à grand-duc Nicolas Osman Paşa' Gran dük Nikol'ya Cevab1 \\
\hline 20. Une autre réponse d'Osman Pacha au grand-duc Nicolas Osman Paşa'nın Gran dük \\
Nikola'ya diğer bir cevab1 \\
\hline
\end{tabular}


21. Un autre réponse héroïque de Moussa Pacha Musa Paşa'nın bir cevab-1 kahramannası

22. Sentiment d'honneur de deux soldats turcs bléssés İki yaralı Türk askerinin hissi hamiyeti

23. Dévouement du soldat Ali Nefer Ali'nin fedakârlığı

24. Le soldat $\sim$ Asker

25. L'amour du drapeau Sancağa muhabbet

26. Dévouement pour son camarade Arkadaşına karşı fedakârlık

27. La Pierre $\sim$ Taş

28. Le portrait $\sim$ Tasvir

29. Dévouement du chevalier d'assas Şövalye D'assas'ın fedakârlığ 1

30. Le jardinier François Bahçevan Fransuva

31. Fidélité au drappeau Sancağa sadakat

32. Le vase du Japon Japon vazoları

33. La noix $\sim$ Ceviz

34. Les liserons $\sim$ Kahkaha çiçekleri

35. L'enfant gaté Şımarık çocuk

36. Aide-toi, le ciel t'aidera Sen kendi kendine yardım et, Allah da sana yardım eder

37. Le cheval vole $\sim$ Çalınmış at

38. L'avarice puni Ceza edilmiş bir tama(tamahkâr)

39. Pardon des injures $\sim$ Aff-1 hakaret

40. Le fer à cheval $\sim$ At nalı

41. Un marin de treize ans $\sim$ Onüç yaşında bir bahriyeli

42. Dévouement et abnégation d'une sentinelle $\sim$ Bir nöbetçi neferinin sadakati ve fedakârlı̆̆ 1

43. Circonspection d'un pacha Bir paşanın ihtiyatı ve basireti

44. Discours de Abdul Ezel pacha devant Lisvaki Lisvaki ... Abdul Ezel Paşa merhumun nutku

45. Courage et bienfaisance d'un paysan $\sim$ Bir köylünün cesaret ve insaniyeti

46. L'aveugle et son chien $\sim$ Ama ve köpeği

47. l'enfant et le morceau de bois $\sim$ Çocuk ve odun parçası

48. Le voleur puni Düçar mücazat olan hırsız

49. L'enfant charitable $\sim$ Şefkatli çocuk

50. La poule volée $\sim$ Çalınmış tavuk

51. Le boiteux Topal

52. Un examen de général Durout $\sim$ General Durot'un bir imtihan

53. La réponse d'un commandant turc $\sim$ Bir Osmanlı kumandanının cevab-1 kahramananesi

54. Acte hérö̈que d'un soldat $\sim$ Bir askerin hareket-i kahramananesi 


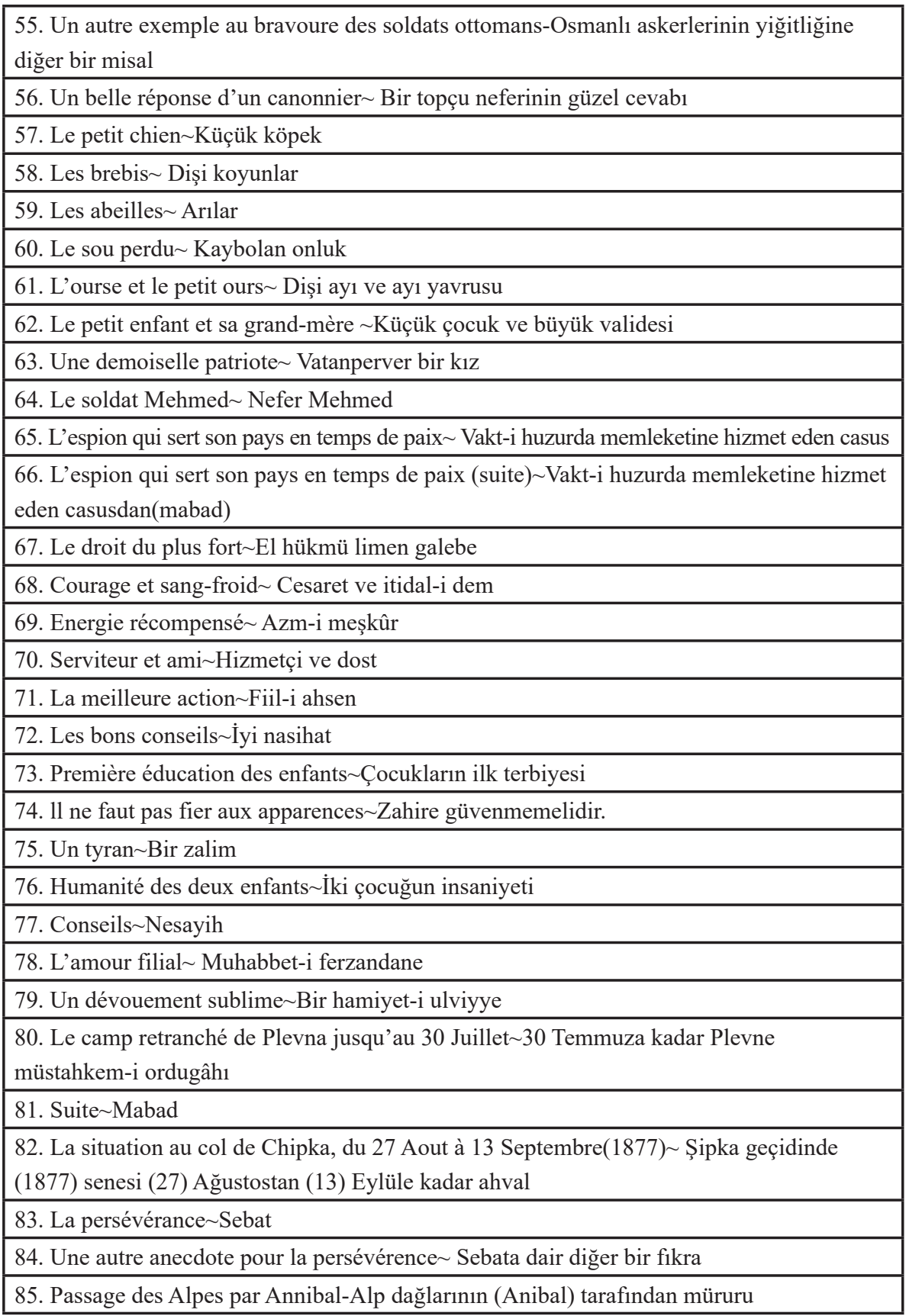


86. La fidélité patriotique $\sim$ Sadakat-i vataniyye

87. Accomplissement du devoir $\sim$ İfay-1 vazife

88. Fidélité à son maitre $\sim$ Efendisine sadakat

89. L'automne $\sim$ Sonbahhar

90. Bédouin et sa jument $\sim$ Bedevi ve kısrağ 1

91. Le courage en face de la mort « Le médecin et le malade » Ölüm karşısında cesaret « Tabip ve hasta »

92. L'hiver Kiş

93. Le travail Say

94. Présence d'esprit et fermeté dans le péril Huzur-u fakir ve tehlikede metanet

95. Le printemps $\sim$ İlkbahar

96. Devoir du soldat $\sim$ Askerin vazifesi

97. Un morceau de Télémaque $\sim$ Télémaque'dan bir parça

98. Le soldat mourant $\sim$ Muhtazar bir asker lisanından

99. Histiore d'un jeune lapin désobéisant $\sim$ İtaatsiz bir tavşan yavrusunun hikâyesi

100. George 11l, roi d'Angleterre et l'aubergiste $\sim$ İngiltere kralı Üçüncü Corç ve lokantacı

$\mathrm{Bu}$ metinlerin başlıklarına bakıldığında daha çok ders içeriklerinde kullanmaya yönelik olarak tercih edildikleri anlaşılmaktadır. Seçilen eserlerin yerel kültüre ait olmasına dikkat edildiği göze çarpmaktadır. Esen-Eruz (2008: 71) her metni oluştuğu koşulların kültürel bir yansıması olarak görür. O’na göre kültürün belirlenen sınırlar içinde bir tür iz düşümüdür metinler. Kültür'ün ise sadece yazınsal metinlerde değil tüm metinlerde önemli bir etkisi vardır. Yukarıdaki kullanmalık metinlerin başlıklarından da anlaşılacağı üzere kitapta askerlik alanıyla ilgili kullanmalık çeviri metinleri ağırlıktadır. Özellikle 40. metinden sonraki çevirilerin çoğu bu alana yöneliktir. 25 metin ağırlıklı olarak askeri terminoloji ve konuları içerir. Bu sayı kitaptaki metinlerin \% 25'i diğer bir deyişle tüm metinlerin dörtte birini oluşturuyor. Kitabın yazarlarının her ikisinin de asker kökenli oluşu bu duruma etken olabilir. Kitabın askeri okulların programına uygun olarak hazırlanması düşüncesi de başka bir etken olarak gösterilebilir. Bunun yanında içinde bulunulan dönemin savaş dolu yıllar oluşu ve sosyokültürel yapısı da diğer önemli bir etken olarak eklenebilir. Bu durum eğitim ortamında çevirmenin içinde bulunduğu sosyokültürel ortam, psikososyal durum ve ekonomik yapı kullanmalık kaynak metin içeriğindeki olay olgu örgüsünü ve seçimini etkilediğini gösterir. 
Kullanmalık metinlerin kitaba yerleştirilmesinde "yansıtmalı" bir çeviri yöntemi tercih edilmiştir. Yansıtmalı yöntemde metinler yerleştirilirken bir sayfada "kaynak metin" diğer sayfada "erek metin” olacak şekilde yani sağlı solu bir yerleşim söz konusudur (Bkz. Ek 3). Burada dikkat çeken nokta; çevrilen metinlerin yabancı dilden ana dile (Version) mi yoksa ana dilden yabancı dile (thème) mi olduğu metinlerin içeriğinden anlaşılabilir bir yapıda olmasıdır. Eserde kaynak/ erek metin ayrımı yapılmamıştır.

Metinlerin çoğunun eğitim ortamı için yazarların kendileri tarafından kaleme alındıkları görülmektedir. Yani Osmanlıca yazıldığı ve Fransızcaya çevrildiği tespit edilmiştir. Bunun yanında yapı ve içerik itibariyle Fransızca kaynaklardan alındığı görülen 8 metin bulunmaktadır. Bu metinlerin başlıkları şöyledir;

- Orgueilleuse-Mütekebbire

- Dévouement du chevalier d'assas- Şövalye D'assas'ın fedakârlığ

- Le jardinier François- Bahçevan Fransuva

- Un examen de général Durout-General Durot'un bir imtihanı

- Passage des Alpes par Annibal-Alp dağlarının (Anibal) tarafından müruru

- Un morceau de Télémaque - Télémaque'dan bir parça

Tanzimat döneminde yapılan ilk çeviri eserlerden biri olduğunu yukarıda belirttiğimiz "Télémaque" bu kitapta da kullanmalık bir metin olarak ele alınmıştır.

Roman, hikâye, masal, fikra gibi edebi türlerden seçilen kullanmalık metinlerin yanında mektup, şiir ve bilgilendirici (tarih, fen, hukuk) metinleri de seçilmiştir. Bilgilendirici metinlerin özel alan çevirileri ile ilgili oluşu dikkat çekicidir. Kitapta şiir sadece bir kez çevrilmiştir. O da Halil Rüştü Bey’e ait "Le soldat mourant - Muhtazar bir asker lisanından” adlı şiirdir. İçinde çocuklara ve gençlere yönelik öğütler içeren "Conseils-Nesayih" ve "Les bons conseils- Iyi nasihatler" gibi iki metin çevrilmiştir. Seçilen hikâye ve masalların tümünde öğüt verici bir içerik bulunmaktadır.

\section{2. Örnek Metinler}

Dolet (1540, 13-19) iyi bir çeviri yapmanın yollarını beş başlıkta açıklamaktadir; 
1. Kaynak metnin yazarının duygu ve niyetini iyi anlayıp; belirgin olmayan, anlaşılmaz yerleri açıklama özgürlüğüne sahip olmak

2. Kaynak dil ve hedef dili çok iyi bilmek

3. Mot à mot çeviriden kaçınmak

4. Ortak kabul görmüş ifadeleri kullanmak

5. En uygun tınıyı elde etmek için sözcükleri uygun şekilde seçip düzenlemek.

Burada temel olarak çevirmenlerin eğitim ortamı için hazırladıkları metinleri çeviri süreçleri bakımından ayrıntılı bir inceleme yapmaktan kaçınılmıştır. Yazarların kendi ifadelerinden olabildiğince "mot à mot" çeviriye yakın (Cemil ve Fehmi, 1911: 2) bir çeviri yapmaya gayret gösterdikleri anlaşılmaktadır. $\mathrm{Bu}$ nedenle betimlemelerin bu çerçevede yapılmasına dikkat edilmeye çalışılmıştır. Örnek metinler çevriyazıları (transkripsiyon) ile birlikte metin bütünlüğünü koruyacak şekilde tam olarak verilmiştir. İçinden metnin tümü yerine dikkat çekici olduğu düşünülen çeviriler seçilerek betimlenmiştir.

1. Örnek: Bu metnin orijinalinin Osmanlıca olduğu görülmektedir. Dolayısıyla Osmanlıcadan Fransızcaya bir çeviri (thème) yapılmıştır.

22. - SENTIMENT D'HONNEUR DE
DEUX SOLDATS TURCS BLESSÉS.
Le lendemain d'un combat où
l'ennemi avait été vainqueur, des soldats
russes trouvèrent deux soldats turcs étendus
sur le champs de bataille; l'un avait la
jambe emportée, l'autre les yeux crevés.
Comme les Russes en les relevant
plaignaient leur sort: "Nous sommes plutôt
dignes d'envie, repondit le premier; je n'ai
pas eu le lâcheté de fuir. -Et moi, ajouta
l'autre, je n'ai point vu notre défaite."
(Cemil ve Fehmi, 1911: 22)

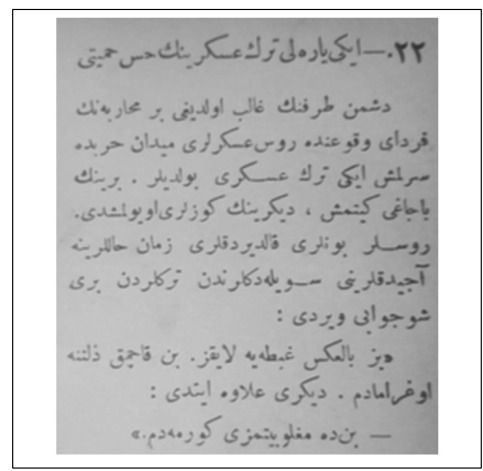

\section{İKİ YARALI TÜRK ASKERININ HISSSI HAMIYETİ}

Düşman tarafının galib olduğı bir muharebenin ferda-yı vukuunda Rus askerleri meydan-1 harbde serilmiş iki Türk askeri buldular. Birinin bacağ 1 gitmiş, diğerinin gözleri oyulmuştu. Ruslar bunları kaldırdıkları zaman hallerine acıdıklarını söylediklerinden Türklerden biri şu cevabı verdi: "Biz bilakis gıptaya layığız. Ben kaçmak zilletine uğramadım." Diğeri ilave etti: "Ben de mağlubiyetimizi görmedim." 
Öncelikle Fransızca/Osmanlıca ile Fransızca/Türkçe çeviri yaparken aradaki temel farkı belirtmek gerekir. 1. Örneğimizden alınan bir tamlamanın çevirilerini ele alalım.

\begin{tabular}{|c|c|c|c|}
\hline $\mathrm{a}$ & 1. Le Soldat & 2.Turc & 3.Bléssé \\
\hline $\mathrm{b}$ & عسكرى & تورك & يار الىى \\
\hline $\mathrm{c}$ & Yaral1 & Türk & Askeri \\
\hline
\end{tabular}

Yukarıdaki tabloda a satırında Fransızca, b satırında Osmanlıca ve c satırında Türkçe sözcükler isim tamlaması oluşturacak şekilde verilmiştir. Tamlamanın Fransızcada 1-2-3 şeklindeki söz dizilişi Osmanlıca ve Türkçede 3-2-1 şeklindedir. Ancak "satırarası (interlinéaire)" çeviride Fransızca ve Osmanlıca sözcüklerin birbiriyle dikey eşitliği görülmektedir. Bunun temel nedeni Osmanlıcanın soldan sağa doğru yazılmasıdır. Tabi bu tabloyu her türlü ifadeyi sağlamada kullanmak olanaksızdır. Bu dikey eşitliğe aykırı birçok durum vardır.

İlk örnek metinden şu cümleyi yöntem bakımından ele alalım.

Ruslar bunları kaldırdıkları zaman hallerine acıdıklarını söylediklerinden Türklerden biri şu cevabı verdi: «Biz bilakis gıptaya layığız. Ben kaçmak zilletine uğramadim.»

Comme les Russes en les relevant plaignaient leur sort: «Nous sommes plutôt dignes d'envie, repondit le premier; je n'ai pas eu la lâcheté de fuir.

$\mathrm{Bu}$ çeviride birebir ya da anlama en yakın söz öbekleri kullanılmaya çalışılmıştır. Özellikle deyimlerin aktarılmasında birebir veya yakın anlamın verilmesine özen gösterilmiştir; "birşeye layık olmak" birebir karşılığıyla "être digne de qqch." deyimiyle karş1lanmıştır. "Zillete uğramak, zillete düşmek” deyimi "avoir la lacheté de qqch." ifadesi ile anlam yakın olarak aktarmaya çalışılmıştır. "Bilakis" sözcüğü birebir şekliyle "au contraire/bien au contraire/à l'inverse”" ile değil cümlenin gelişine uygun olarak "plutôt" ile karşılanmıştır.

2. Örnek: Bu metnin orijinali halk arasında anlatılan bir hikâyedir. Osmanlıca olduğu görülmektedir. Dolayısıyla Osmanlıcadan Fransızcaya bir çeviri (thème) yapılmıştır. 


\section{6.- LA POULE}

Une pauvre vieille femme possédait une poule qui lui pondait tous les jours un œuf. Ne voulant pas se contenter d'un seul œuf, elle engraissa la poule, croyant de cette manière obtenir deux ou trois par jours. Mais la surabondance de nourriture rendit la poule trop grasse, et elle cessa de pondre (Cemil ve Fehmi, 1911: 10-11).

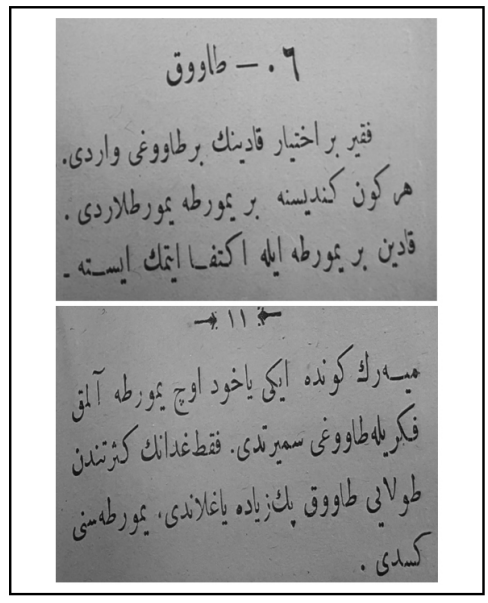

\section{6. - Tavuk}

Fakir bir ihtiyar kadının bir tavuğu vardı. Her gün kendisine bir yumurta yumurtlardı. Kadın bir yumurta ile iktifa etmek istemeyerek günde iki yahut üç yumurta almak fikriyle tavuğu semirtti. Fakat gıdanın kesretinden dolayı tavuk pek ziyade yağlandı. Yumurtasını kesti.

Çeviri edinci için hazırlanacak kullanmalık metinler sıkıcı ve zorlayıcı olmamalıdır. Bu konuda şu ifadeler yol gösterici olabilir. "Metin okuru ne sıkmalı ne de fazla zorlamalıdır, dahası okur metni okumanın ve alımlamanın kendisi için bir anlamı olduğuna inanmalıdır. Metin okurun beklentisine uygun olduğu sürece ilginçtir." (Esen-Eruz, 2008: 135). Çeviri edinci sürecindeki metinlerde de aynı özellikleri taş1malıdır. Böyle kullanmalık metinler metin gülümseten ve öğüt verici niteliği ile süreci daha eğlenceli hale getirebilir.

Fakir bir ihtiyar kadının bir tavuğu vardı. Her gün kendisine bir yumurta yumurtlardl.

Une pauvre vieille femme possédait une poule qui lui pondait tous les jours un oеuf.

Yukarıdaki iki farklı cümle Fransızcaya çevrilirken tek cümle olarak birleştirme yoluna gidilmiştir.

Kadın bir yumurta ile iktifa etmek istemiyerek günde iki yahud üç yumurta almak fikiriyle tavuğu semirtti.

Ne voulant pas se contenter d'un seul oeuf, elle engraissa la poule, croyant de cette manière obtenir deux ou trois par jours. 
Yukarıdaki çeviride "iktifa etmek" deyimi Fransızcaya "se contenter de qqch.” yapısı ile yakın anlamıyla karşılanmıştır. Yine cümlenin gelişine uygun düşmesi için “... fikriyle” yani “... düşüncesiyle” ifadesi "croyant de” yapısı ile yakın anlamıyla aktarılmıştır.

Fakat gıdanın kesretinden dolayı tavuk pek ziyade yağlandı. Yumurtasını kesdi.

Mais la surabondance de nourriture rendit la poule trop grasse, et elle cessa de pondre.

Burada da iki farklı cümle birleştirme yapılarak tek cümle haline getirilmiştir ve metnin gelişinden çevirinin nasıl kurgulanacağını sezen ve gören çevirmen ifadeyi en kısa yoldan anlamlı bir şekilde aktarmayı düşünmüştür. "Görme eylemi” çevirmenin en önemli çeviri edinçlerinden biridir.(Esen-Eruz, 2008: 9697). Yukarıda verilen iki birleştirme örneğinde çevirmen/öğreticinin görme eylemini gerçekleştirip ifadeyi hedef dilin yapısına uygun bir yapıda vermeye çalıştığ da söylenebilir. 
3. Örnek: Bu metnin farklı kültürlerde değişik şekillerde anlatılan bir hikâyedir. Buradaki çeviri Osmanlıcadan yapılmışıtır. Osmanlıcadan Fransızcaya bir çeviri (thème) yapılmıştır.

\section{9. - LES TROIS BRIGANDS.}

Trois brigands attaquèrent un voyageur qui traversait une épaise fôret. Après l'avoir assasiné, ils pillièrents a voiture, chargée de quantité d'argent et d'effets précieux, et transportèrent dans leur caverne le trésor si mal acquis; puis il envoyèrent le plus jeune d'entre eux à la ville pour leur procurer des vivres.

Lorsqu'il fut parti les deux qui étaient restés se disaient l'un à l'autre: “À quoi bon partager avec ce drôle de si belles dépouilles? Tuons-le dès qu'il sera rentré, et sa part du trésor grossira la nôtre.

Chemin faisant, le jeune brigand de son côté, pensait en lui-même: "Que je serais heureux si la totalité du trésor m'appartenait! Je vais empoisonner mes deux compagnons, et toutes nos richesses appartiendront à moi seul."

Arrivé à la ville, il fit sa provision de vivres, jeta du poison dans le vin et se remit en route pour retourner vers ses camarades.

Aussitôt qu'il eut mis le pied dans la caverne, les deux autres s'élancèrent sur lui et lui enfoncèrent leur poignards dans le cœur... 11 tomba raid mort. Ensuite les deux scélérats se jetèrent sur les vivres, et se mirent à manger et à faire de copieuse libtations du vin empoisonné..... Eux aussi expirèrent dans des douleurs épouvantables, et l'on trouva leur cadavres au milieu des trésors qu'ils avaient volés (Cemil ve Fehmi, 1911: 13-15).

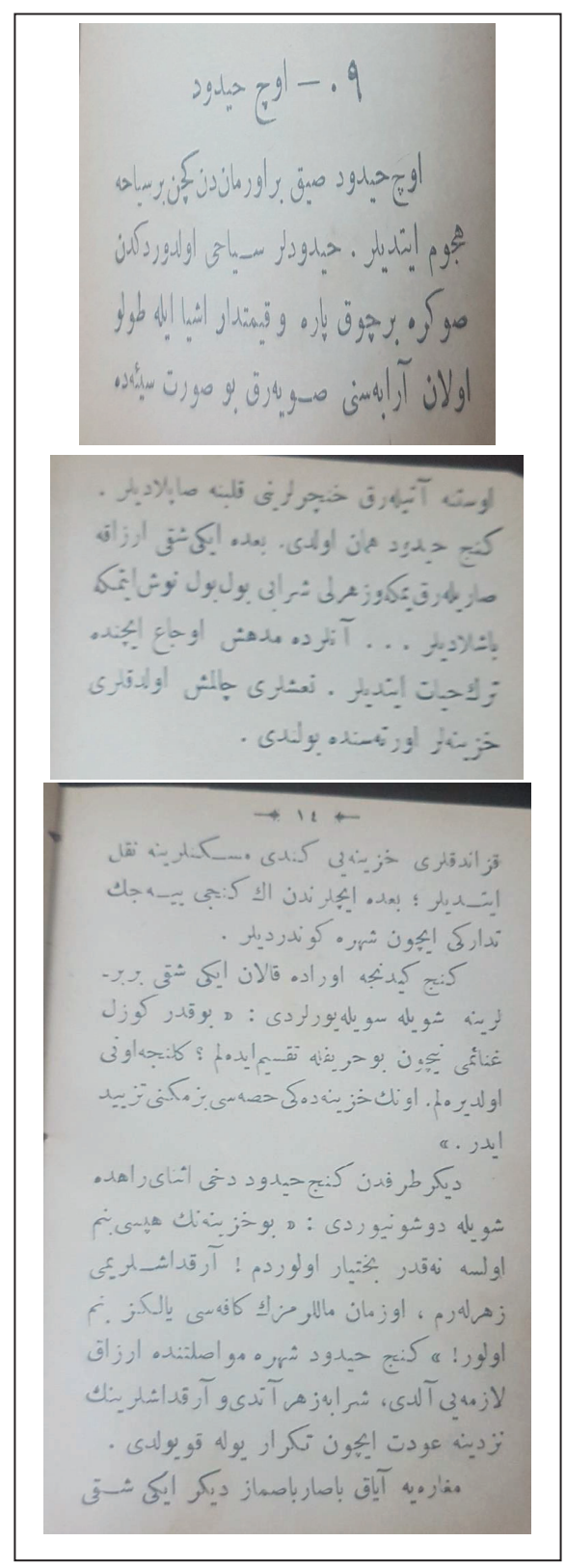




\section{ÜÇ HAYDUT}

Üç haydut sık bir ormandan geçen bir seyyaha hücum ettiler. Haydutlar seyahı öldürdükten sonra birçok para ve kıymettar eşya ile dolu olan arabasını soyarak bu suret-i seyyiahdu kazandıkları hazineyi kendi meskenlerine nakil ettiler; bade içlerinden en genci yiyecek tedaraki için şehre gönderdiler. Genç gidince orada kalan şaki birbirlerine şöyle söylüyorlardı: $\mathrm{Bu}$ kadar güzel ganimi niçin bu herifle taksim edelim? Gelince onu öldürelim. Onun hazinedeki hasası bizimkini tezid eder. Diğer taraftan genç haydut dahi esnai rahde şöyle düşünüyordu: $\mathrm{Bu}$ hazinenin hepsi benim olsa ne kadar bahtiyar olurdum! Arkadaşlarımı zehirlerim, o zaman mallarımızın kâfisi yalnız benim olur! Genç haydut şehre musallatında erzak-ı lazımayı aldı, şaraba zehir attı ve arkadaşlarının nezdine avdet için tekrar yola koyuldu. Mağraya ayak basar basmaz diğer iki şaki üstüne atılarak hançerlerini kalbine sapladılar. Genç haydut hemen öldü. Bade iki şaki erzaka sarılarak yemeye ve zehirli şarabı bol bol nuşayetmeye başladılar... Onlar da midehoş acı içinde terk-i hayat ettiler. Naaşları çalmış oldukları hazineler ortasında bulundu.

Üç haydut s1k bir ormandan geçen bir seyyaha hücum ettiler.

Trois brigands attaquèrent un voyageur qui traversait une épaise fôret.

$\mathrm{Bu}$ çeviride birebir aktarım yapıldı̆̆ı gözlemlenmektedir. Herhangi yan anlam ifade edebilecek bir kullanım da yoktur.

Bu kadar güzel ganimi niçin bu herifle taksim edelim? Gelince onu öldürelim. Onun hazinedeki hasası bizimkini tezid eder.

À quoi bon partager avec ce drôle de si belles dépouilles? Tuons-le dès qu'il sera rentré, et sa part du trésor grossira la nôtre.

"Niçin" soru edatı "À quoi bon” ifadesiyle karşılanmıştır. Birebir çeviri yerine anlamdan hareketle hedef dilde karşılığı verilmeye çalışılmıştır. Yine "bu herifle" ifadesi "avec ce drôle" yapısında hedef dile aktarılmıştır. Sonraki iki cümle birleştirilerek aktarılmış, anlam bütünlüğü korunmuştur. Burada yapılan çeviriyle ilgili şu bilgileri vermek gerekir; "Çevirmen metni erek dile aktarırken kültürel boyut katmanlaşarak karşısına çıkar. Kaynak kültürü çözümleyen çevirmen, bu çözümü erek kültürün anlayacağı şekilde erek kültüre aktarmakla yükümlüdür. (Esen-Eruz, 2008: 72). Yukarıda yapılan çevirileri bu yaklaşım çerçevesinde ele almak gerekir.

Diğer taraftan genç haydut dahi esnai rahde şöyle düşünüyordu: Bu hazinenin hepsi benim olsa ne kadar bahtiyar olurdum!

Chemin faisant, le jeune brigand de son côté, pensait en lui-même: "Que je serais heureux si la totalité du trésor m'appartenait!

"esnai rahde” ifadesi Fransızcaya "chemin faisant” şeklinde aktarılmış, erek kültürü yansıtacak şekilde anlamlandırılmıştır. 
4. Örnek: Bu metnin içinde hukuk terimleri de barındıran bir hikâyedir. Buradaki çevirinin Osmanlıcadan yapılmış olduğu görülmektedir. Osmanlıcadan Fransızcaya bir çeviri (thème) yapılmıştır.

\section{0. - JUGEMENT REMARQUABLE D'UN JUGE.}

Un marchand, ayant confié à un conducteur de chameaux un certain nombre de balles de soie pour les transporter d'une ville à l'autre, se mit en chemin avec lui; mais, au milieu de la route, il tomba malade ne put suivre la caravane qui arriva à la destination longtemps avant lui.

Le chamelier ne voyant pas revenir le marchand au bout de plusieurs semaines, s'imagina qu'il était mort, vendit la soie pour son compte et changea de profession. Le marchand arriva enfin, et après avoir perdu bien du temps à chercher le chamelier le trouva et lui demanda ses marchandises.

Le fourbe chamelier feignit de ne pas le connaître et nia avoir été jamais chamelier.

Le marchand a porté la constetation devant le juge de la ville. Celui-ci leur dit à tous deux qu'ils n'avaient pas les preuves suffisantes pour faire valoir leur cause et leur ordonna de se retirer de sa présence. Il leur tourna le dos, et pendant qu'ils sortaient ensemble, $\underline{\text { ils se mit à }}$ une fenêtre et cria assez haut: "Chamelier! Un mot!"

Celui-ci qui avait été chamelier tourna aussitôt la tête sans songer qu'il venait de renier cette profession. Alors le juge l'obligeant de retourner sur ses pas, lui fit donner une belle bastonade et avouer sa friponnerie. Il le condamna à indamniser au la marchand la soie voée et, de plus, une amende considérable pour le faux serment qu'il avait prêté (Cemil ve Fehmi, 1911: 15-17).

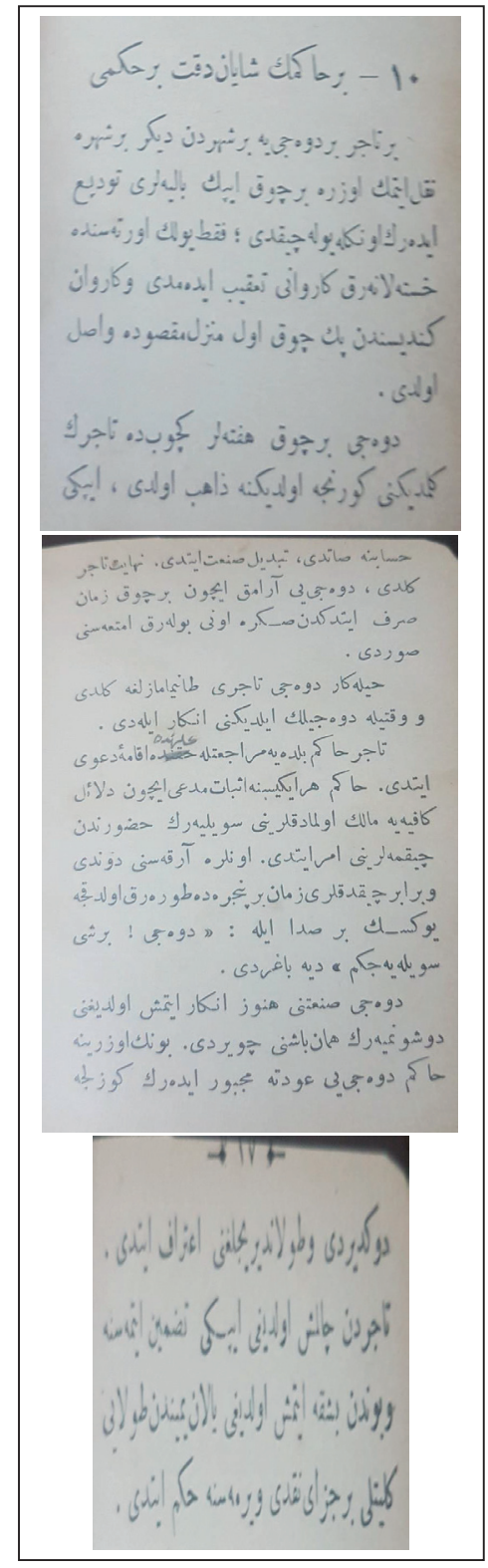




\section{BIIR HÂKİMIN ŞAYANA DEGER BİR HÜKMÜ}

Bir tacir, bir deveciye bir şehirden diğer şehre nakil etmek üzere birçok ipek balyaları tevdiye ederek o nakille yola çıktı; fakat yolun ortasında hastalanarak karavanı takip edemedi ve karavan kendisinden pek çok evvel menzil-i maksude vasıl oldu. Deveci birçok haftalar geçipte tacirin gelmediğini görünce zehb olduğu, ipeği hesabına sattı, tebdili sanaat etti. Nihayet tacir geldi, deveciyi aramak için birçok zaman sarfettikten sonra onu bularak emtaasını(emtiyasını) sordu.

Hilekâr deveci taciri tanımazlığa geldi ve katile deveciliğinin olduğunu inkâr eyledi.

Tacir, hâkim-i beldeye müracaatla hakkında ikam-1 dava etti. Hâkim her ikisini ispat-1 medayı için delil-i kafiyeye malik olduklarını söyleyerek huzurundan çıkmalarını emretti. Onlara arkasını döndü ve beraber çıktıkları zaman bir pencerede durarak oldukça yüksek bir seda ile : "Deveci! Bir şey söyleyeceğim.” diye bağırdı.

Deveci sanaatini henüz inkâr etimiş olduğunu düşünmeyerek hemen başını çevirdi. Bunun üzerine hâkim deveciyi avdete mecbur ederek dövdürdü ve dolandırıcılığını itiraf etti. Tüccardan çalmış olduğu ipeği tazmin etmesine ve bundan başka etmiş olduğu yalan yeminden dolayı kaliteli bir cezay-1 nakdi vermesine hükmetti.

Yukarıda metinde altı çizili şekilde belirtilrn "İls" ve "indamniser” sözcüklerinin yazımında yanlışlık vardır. Kullanımlık metinlerdeki bu tür eksiklikerin çalışmalara başlanmadan önce giderilmesi gerekmektedir.

Deveci birçok haftalar geçipte tacirin gelmediğini görünce zehb olduğu, ipeği hesabına sattı, tebdili sanaat etti.

Le chamelier ne voyant pas revenir le marchand au bout de plusieurs semaines, s'imagina qu'il était mort, vendit la soie pour son compte et changea de profession.

Bu çeviride "gelmediğini görünce” ifadesi yakın anlamıyla "ne voyant pas revenir "şekliyle verilmiştir. "tebdili sanaat etti." anlatımı "changea de profession. " olarak birebir aktarılıştır.

Tacir, hâkim-i beldeye müracaatla hakkında ikam-ı dava etti.

Le marchand a porté la constetation devant le juge de la ville

Yukarıdaki çeviride "ikam-ı dava etti." ifadesi anlamı karşılayacak şekilde "porté la constetation" kalıbıyla karşılanmıştır. Ayrıca bu ifadenin bir hukuk terimi olduğunu da belirtmek gerekir. "Harfler ve sözcükleri çözümlemek ancak 
tanıdık bir bağlamda olanaklıdır, başka bir deyişle okurun donanımı ve uzmanlık bilgisi metindeki bilgilerle kısmen örtüşmek zorundadır.” (Esen-Eruz, 2008: 134). Bu tür uzmanlık gerektiren terimleri içeren kullanımlık metinlerin aktarımında öğrencilerin donanımının yeterli olmasına özen gösterilmelidir.

Onlara arkasını döndü ve beraber çıktıkları zaman bir pencerede durarak oldukça yüksek bir seda ile : “Deveci! Bir şey söyleyeceğim.” diye bağırdl.

Il leur tourna le dos, et pendant qu'ils sortaient ensemble, ils se mit à une fenêtre et cria assez haut: "Chamelier! Un mot!"

"Deveci! Bir şey söyleyeceğim” cümlesi "Chamelier! Un mot!" yap1sında tam bir kültürel aktarımla anlamlandırılmıştır. "Un mot" ifadesi "birşey söyleyeceğim" yapısına karşılık olarak çivirilmiştir. 
“Deveci! Bir şey söyleyeceğim” cümlesi "Chamelier! Un mot!” yapısında tam bir kültürel aktarımla anlamlandırılmıştır. "Un mot” ifadesi "birşey söyleyeceğim” yapısına karşılık olarak çivirilmiştir.

5. Örnek: Bu metinde Fransızcadan Osmanlıcaya çeviri (version) yapılmıştır. Metin Fénélon'un başyapıtı Télémaque'dan bir parçadır. Metnin çevirisi bu kitabın yazarları tarafından yapılmamıştır. Kitaba alınan çeviri Ahmet Vefik Paşa tarafından yapılmıştır.

Vefik Paşa Hüdavendigar yani bugünkü Bursa ve ahalisinde valilik yapmış Arnavut asıllı meşhur Osmanlı devlet adamıdır. Çeviri bu yönüyle dikkate değerdir. Zamanın estetik özelliklerini yansıtır nitelikte bir aktarımdır.

\section{UN MORCEAU DE TÉLÉMAQUE}

Calypso, étonné et attendri de voir dans une si vive jeunesse tant de sagesse et d'éloquence, ne pouvait rassasier ses yeux en le regardant; et elle demeurait en silence. Enfin elle lui dit: Télémaque, nous vous apprendrons ce qui est arrivé à votre père.

Mais l'histoire en est longue: il est temps de vous délasser de tous vos travaux. Venez dans ma demeure, où je vous recevrai comme mon fils: venez; vous serez ma consolation dans cette solitude, et je ferai votre bonheur, pourvu que vous sachiez en jouir.

Télémaque suivait la déesse accompagnée d'une foule de jeunes nymphes, au-dessus desquelles elle s'élevait de toute la tête, comme un grand chêne, dans une forêt, élève ses branches épaisses au-dessus de tous les arbres qui l'environnent. Il admirait l'éclat de sa beauté, la riche pourpre de sa robe longue et flottante, ses cheveux noués par derrière négligemment, mais avec grâce, le feu qui sortait de ses yeux, et la douceur qui tempérait cette vivacité. Mentor, les yeux baissés, gardant un silence modeste, suivait Télémaque.

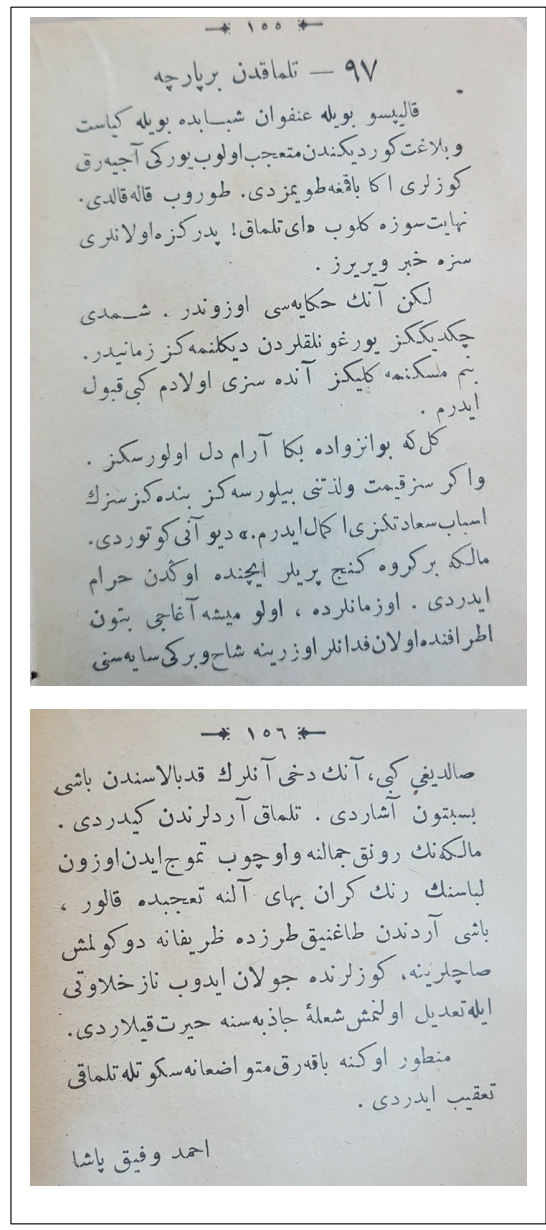




\section{TELEMAKDAN BİR PARÇA}

Kalipso böyle ünfuvan-i şebabda böyle kiyaset ve belagat gördüğünden müteaccib olub, yüreği acıyarak gözleri ona bakmaya doymazdı. Durub kalakaldı. Nihayet söze gelüp ; « Ey Telemak! Pederinize olanları size haber veririz.

Lakin onun hikayesi uzundur. Şimdi çektiğiniz yorgunluklardan dinlenmeniz zamanıdır. Benim meskenime geliniz, onda sizi evladım gibi kabul ederim.

Gel ki bu inzivada bana aramdil olursunuz. Ve eğer siz kıymet ve lezzetini bilür iseniz bendeniz sizin esbabı saadetinizi ikmal ederim. Deyu onu götürdü.

Malike bir güruh genç periler içinde önden haram ederdi. O zamanlarda ölü meşe ağacı bütün etrafında olan fidanlar üzerine şah ve berki sayesini saldığı gibi onda dahi onların kaddı balasından başı büsbütün aşardı. Telemak artlarından giderdi. Malikenin revnakı cemaline ve uçup temevvüc eden uzun libasının renk giranı bahay-1 alına taacüpte kalur, başı ardından dağınık tarzda zarifane dökülmüşs saçlarına, gözlerinde cevelan edip nazı hilaveti ile tadil olunmuş şulei cazibesine hayret kılardı. Mantor önüne bakarak mütevaziyane sükutla Telemak1 takip ederdi.

Ahmet Vefik Paşa

“étonné” ve "attendri” sözcükleri yazılırken özne uyum yapılası gerekir. Yazım yanlışı burada da vardır. Doğru yazım "étonnée" ve "attendrie” şeklinde olmalıdır. Kullanımlık metinlerdeki bu tür eksiklikerin önceden giderilmesi gerektiğine değinilmişti.

Calypso, étonné et attendri de voir dans une si vive jeunesse tant de sagesse et d'éloquence, ne pouvait rassasier ses yeux en le regardant; et elle demeurait en silence.

Kalipso böyle ünfuvan-i şebabda böyle kiyaset ve belagat gördügünden müteaccib olub, yüreği acıyarak gözleri ona bakmaya doymazdl. Durub kalakaldı.

Yukarıdaki tek cümlelik ifade Osmanlıcaya iki cümle şeklinde bölünerek aktarılmıştır. Anlam kayıplarını en aza indirecek şekilde mot à mot'ya yakın bir çeviri yapılmıştır. Bu durum cümle bölümlendiğinde daha açık bir şekilde ortaya çıkmaktadır.

Calypso-Kalipso

étonné et attendri de voir dans- gördüğünden müteaccib olub, yüreği actyarak une si vive jeunesse- böyle ünfuvan-i şebabda

tant de sagesse et d'éloquence- böyle kiyaset ve belagat 
ne pouvait rassasier ses yeux en le regardant gözleri ona bakmaya doymazd et elle demeurait en silence- Durub kalakald

Çevirmen/yazarın yeteneği bu satırlarda görülmektedir. Kitabın yazarları bu yeteneği görmüş olacak ki çeviriyi kullanmalık bir metin olarak eserlerine almişlar.

Mentor, les yeux baissés, gardant un silence modeste, suivait Télémaque.

Mantor önüne bakarak mütevaziyane sükutla Telemak 1 takip ederdi.

Yukarıdaki cümlede yine bire bir çeviriye uygun bir aktarım görülmektedir.

Venez dans ma demeure, où je vous recevrai comme mon fils: venez; vous serez ma consolation dans cette solitude, et je ferai votre bonheur, pourvu que vous sachiez en jouir.

Benim meskenime geliniz, onda sizi evladım gibi kabul ederim. Gel ki bu inzivada bana aramdil olursunuz. Ve eğer siz klymet ve lezzetini bilür iseniz bendeniz sizin esbabı saadetinizi ikmal ederim. deyu onu götürdü.

$\mathrm{Bu}$ cümlede kitap yazarlarının "Esna-yı tercümede cümlelerin parlak, mustalah olmasından ziyade..." ifadelerden anlaşılıyor ki süslü ve güzel cümle değil birebir anlamı yada buna en yakın anlamı vermeye çaba göstermişler. Ancak yukarıdaki çevirilerde Ahmet Vefik Paşanın edebi kimliğini de çevirisine yansıttı̆̆ süslü yapılardan anlaşılmaktadır.

pourvu que vous sachiez en jouir-Ve eğer siz klymet ve lezzetini bilür iseniz et je ferai votre bonheur - bendeniz sizin esbabı saadetinizi ikmal ederim, deyи опи götürdü.

Yukarıdaki alıntı buna bir örnektir. Cümlenin şu kısmı ;

"Gel ki bu inzivada bana aramdil olursunuz. Ve eğer siz klymet ve lezzetini bilür iseniz bendeniz sizin esbabı saadetinizi ikmal ederim. deyu onu götürdü." güncel dil ve yalın aktarımla "Gelin, gelin de bu yanlızlıkta tesellim olursunuz. Yeterki siz keyfini çıkarın, ben de sizi mesut ederim” şeklinde çevrilebilir. Süslü yapı ile aradaki fark1 göstermek için verdiğimiz çeviri örneği "Cümlenin doğru çevirisi budur.” şeklinde bir yargıya götürmemelidir. Çevrildiği dönemin şartları, estetik bakış açısı, dil tercihleri ve belkide “skopos'u” bu tür süslü bir çeviriyi gerektirebilir, 


\section{Sonuç}

Bir eğitim ortamını, çeviri öznesi çevirmenin içinde bulunduğu sosyokültürel ortam, pisikososyal durum ve ekonomik yap1 şekillendirir, kaynak metin, olay, olgu seçimini etkiler. Çeviri eğitimi sırasında günümüz çeviri ihtiyaçları ve piyasa talepleri doğrultusunda örnek metinler belirlenmektedir. Bu çalışmada artsüremli diliçi çeviri ve dillerarası (intralangue/interlangue) çeviri uygulamaları birlikte ele alınmaya çalışılmıştır. Osmanlının son döneminde yapılan çalışmaların nitelikleri ortaya konulup, çeviri uygulamaları, seçilen konular, içerik ve yöntem bağlamında betimsel analizler yapılmıştır. Böylece imparatorluğun son dönemlerinde gerçlekleştirilen çeviri tarihi çalışmalarına küçük bir ışık tutulmaya çalışılmıştır.

"Çevirmen ayrı ayrı kültürlerde doğru yolu bulabilen ya da doğru yolu bulmak için işlevsel karar alan ve işlevsel yanıt alabileceği kimselere doğru soruları sormasını bilen ve bu alanda mümkün olduğunca nesnel davranan kişidir. Çevirmen sürekli araştırma yapan ve nerede, neyi araştıracağını bilen bir uzman olmak zorundadır. Çevirmenin danışma hattı bir sözlük ya da bir ansiklopedi, internet olabileceği gibi, o konunun uzmanı da olabilir.”(Esen-Eruz, 2008: 72). Alanda çalışanların nerede, neyi araştıracağına yönelik ipuçları bulmada bu tür betimsel çalışmalar yol gösterici olabilir. Osmanlı tarihinde çevri alanında uzmanlaşmak isteyen biri Osmanlıca'dan Fransızca, İngilizce, Almanca vb. diğer dillere aktarım yapabilecek yeterliğe ulaşmak için başlangıç düzeyinde bu tür kaynaklardan da mutlaka yararlanması gerekecektir. Uzmanlık metinlerini okuyup, artsüremli çözümünü yapıp ardından diğer dillere aktarması gerekecektir. Bu metinlerin çeviri derslerinde ele alınması Türkçenin, Fransızcanın diğer çalışma dillerinin zaman içindeki değişim ve gelişiminin saptanmasında çevirmen adaylarına katkı sağlayacaktır. Osmanlı son döneminde rüştiye (ortaokul) ve idadilere (lise) yönelik çeviri etkinlikleri için, kullanmalık metinler ve bunların çevirilerini içeren çalışmaların varlığı görülmüştür. Bu kullanmalık metinlerde dönemin izlerini taşıyan içerik ve terimlerin olduğu tespit edilmiştir. Bu içerik ve terminolojinin ele alınan eserde askeri alanda yoğunlaştığı belirlenmiştir. Ayrıca dönemin ahlaki değerlerini içeren ders verici çeviri metinler de yer almaktadır. Çalışma konusu kullanmalık metin çevirilerinde genellikle birebir çeviri ya da en yakın 
anlamı verecek ifadelerin yalın olarak verilmeye çalışıldığı görülmüştür. Buna aykırı biçimde verilen örnekleri de görmek mümkündür. İçeriklerde konu zenginliği olduğu kadar tür çeşitliliği de sağlanmaya çalışılmıştır. Ancak bunların eşit ya da dengeli bir oranla yerleştirildiğini söylemek pek mümkün değildir. 


\section{Kaynakça}

Akyüz, Yahya (1987). Atatürk’ün Türk Eğitim Tarihindeki Yeri, Atatürk Arastırma Merkezi Dergisi, Kasım 1987, Cilt, 4, Say1, 10, s, 71-90.

Aktepe, Münir(1989) AHMED III, TDV İslâm Ansiklopedisi, 2. Cilt, s.s. 34-38, İstanbul.

Aydın, Bilgin (2007) Divan-I Hümayun Tercümanları Ve Osmanlı Kültür Ve Diplomasisindeki

Yerleri, Osmanlı Araştırmaları XXIX, s.s. 41-86

Bacqué-Grammont, Jean-Louis (1997). A propos de Yûnus Beg, Baş Tercüman de Soliman le Magnifique, Varia Turcica, XXXI, İstanbul et les Langues Orientales Par Frédéric Hitzel, Editions Harmattan, s. 23-39. Paris.

Balcı, Sezai (2006) Osmanlı Devleti'nde Tercümanlı ve Bab-ı ali Tercüme Odası, Ankara Üniversitesi Sosyal Bilimler Enstitüsü Tarih (Yakınçağ Tarihi) Anabilim Dalı, Tez Danışmanı: Yrd. Doç. Dr. İlknur Haydaroğlu, Yayınlanmamış Doktora Tezi.

Baysal, Jale (2010) Müteferrika'dan Birinci Meşrutiyete kadar Osmanlı Türklerinin bastıkları kitaplar:1729-1875(Kitapların tam listesi ile) 2. Bask1, Hiperlink, İstanbul.

Beyoğlu, Süleyman (2001) Kâmil Paşa, Yûsuf, TDV İslâm Ansiklopedisi, 24. cild, s.s. 283284, İstanbul

Bolay, Süleyman Hayri (2002) Tanzimat'tan Cumhuriyet'e Türk Düşünce Tarihi, Türkler, Cilt: 14 s.s. 515-566 Yeni Türkiye Yayınları, Ankara.

Bozkurt, Nebi(2011) Tercüme 1. Bölüm. TDV İslâm Ansiklopedisi, 40. Cilt, s. 490

Budak, Ali (2013) Batıl1laşma ve Türk Edebiyatı-Lale Devri'nden Tanzimat'a Yenileşme, Bilge Kültür Sanat, İstanbul.

Cemil, Mehmet; Fehmi, Hüseyin, (1911). Fançais-Turc, Modèles de Traduction, Tefeyyuz Kitaphanesi, İstanbul.

Demircioğlu, Cemal (2016) Çeviribilimde Tarih ve Tarihyazımı, Boğaziçi Üniversitesi Yayınevi, İstanbul.

Dolet, Etienne (1540) La Manière de Bien Traduire d'une Langue en Aultre. D'avantage,

De la Punctuation de la Langue Francoyse. Plus, Des accents d'ycelle., Chez Dolet même, Lyons.

Esen-Eruz, Sakine (2008) Akademik Çeviri Eğitimi - Çeviri Amaçlı Metin Çözümlemesi, Multilingual, İstanbul.

Güran, Ceyhan (2007) Bir Dünya İmparatorluklar Merkezi İstanbul, Akis kitap, İstanbul.

Karadağ, A . (2014). Çeviri Tarihimizde Fennî Romanlarla Bir Kültür Repertuarı Oluşturmak. İstanbul Üniversitesi Çeviribilim Dergisi , 3 (6) , 45-73

Kayaoğlu, Taceddin (1998) Türkiye’de Tercüme Müesseseleri, Kitabevi, İstanbul. 
İpşirli, Mehmet (1987) Lâle Devrinde Teşkil Edilen Tercüme Heyetine Dair Bazı Gözlemler, Osmanlı İlmî ve Meslekî Cemiyetleri, s. 33-42; İstanbul.

Uzun, Mustafa (2006) Nahîfî, TDV İslâm Ansiklopedisi, 32. Cilt, s.s. 297-299, İstanbul.

Paker, Saliha (1987) Tanzimat Döneminde Avrupa Edebiyatından Çeviriler, Çoğul-dizge Kuramı Açısından Bir Değerlendirme, (çev. Ali Tükel), Metis Çeviri, 1, 31-43.

Paker, Saliha (1986) Translated European Literature in the Late Ottoman Literary Polysystem, New Comparison, 1, 67-79.

Pym, Anthony (1997) Pour une Éthique du Traducteur, Artois Presses Université, France.

Savory, Theodore (1994), Tercüme Sanatı, Çev. Prof. Hamit Dereli, MEB Yayınları, İstanbul.

Semercioğlu, Ufuk (2010) Osmanlı'da İlk Çeviri Eleştirileri, Buca Eğitim Fakültesi Dergisi, Say1 28 , s.s. $29-38$

Şakiroğlu, Mahmut H.(2011) Tercüme 2. Bölüm. TDV İslâm Ansiklopedisi, 40. Cilt, s. 491

Tahir-Gürçağlar, Şehnaz (2005) Kapılar-Çeviri Tarihine Yaklaşımlar, Scala Yayıncılık, İstanbul.

Ülken, Hilmi Ziya (2016) Uyanış Devirlerinde Tercümenin Rolü, 1. Baskı Vakit Gazete Matbaa Kütüphane-1935 Türkiye İş Bankası Yayınlarından 2. Baskı 2016, İstanbul.

Yalçın, Perihan (2015) Çeviri Stratejileri Kuram ve Uygulama, Grafiker Yayınları, Ankara.

Yazıcı, Mine (2004) Çeviri Etkinliği, Multilingual, İstanbul.

Yazıc1, Mine (2005) Çeviribilmin Temel Kavram ve Kuramları, Multilingual, İstanbul.

\section{Sözlükler}

Aucher, P. Pascal (1840) Dictionnaire Français-Arménien-Turc, Imprimerie de Saint Lazare, Venise.

Bianchi, Thomas Xavier (1831) Vocabulaire Français-Turc à l'usage des interprètes, des commerçans, des navigateurs, et autres voyageurs dans le Levant. Everat Imprimeur de la Societé de Géographe, Paris.

Bianchi,Thomas Xavier (1843) Dictionnaire Français-Turc à l>usage des agents diplomatiques et consulaires, des commerçants, des navigateurs et autres voyageurs dans le Levant, Typographie de Mme V. Dondey-Dupré, Paris.

Hançeri, Alexandre (1841) Dictionnaire Français-Arabe-Persan et Turc enrichi d'exemples en langue turque avec des variantes, et de beaucoup de mots d'arts et de sciences. L'imprimerie de l'Université impériale, à Moscou.

Hindoglu, Artin (1831) Dictionnaire abrégé Français-Turc, F. Beck libraire, Vienne.

Kélékian, Diran (1911) Dictionnaire Turc-Français, (Kâmus-1 Fransavî), Imprimerie Mihran, İstanbul. 
Mallouf, Nassif (1856) Dictionnaire Français-Turc, avec la prononciation figurée, 2e édition corrigée et considérablement augmentée, Maisonneuve, Paris.

Nazima, Ali (1910) Dictionnaire Tefeyuz Ottoman-Français à l'usage des écoles Sultanié et Idadié, Editeur et imprimeur Parsekh, Imprimerie Kasbar, İstanbul.

Redhouse, James W. (1856) English and Turkish Dictionary, Bernard Quaritch Oriental and Philological Publisher, London.

Rhasis, Georges (1828) Vocabulaire Français-Turc, L'imprimerie de l'Académie impériale des sciences, St-Pétersbourg.

Sami, Şemseddin (1883) Dictionnaire Turc-Français, Imprimerie Mihran, İstanbul

Wssehrd, O. de Schlechta (1870) Manuel Terminologique Français-Ottoman, Imprimerie impériale, Vienne.

Youssouf, R. (1890) Dictionnaire portatif Turc-Français de le langue usuelle en caractères latins et turcs. Ouvrage approuvé par le Ministère de l'Instruction publique, İstanbul.

Zenker, Jules Théodore (1866-1876) Dictionnaire Turc-Arabe-Persan, Wilhem Engelmann libraire-éditeur, Leipzig.

\section{Ekler}

Ek1:Kitap Kapak

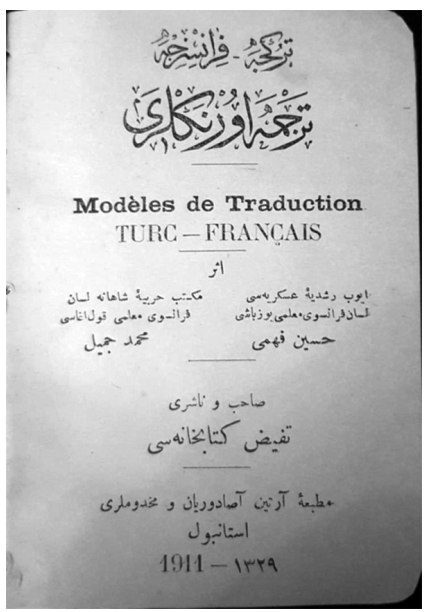

Ek2:Kitap Kapak

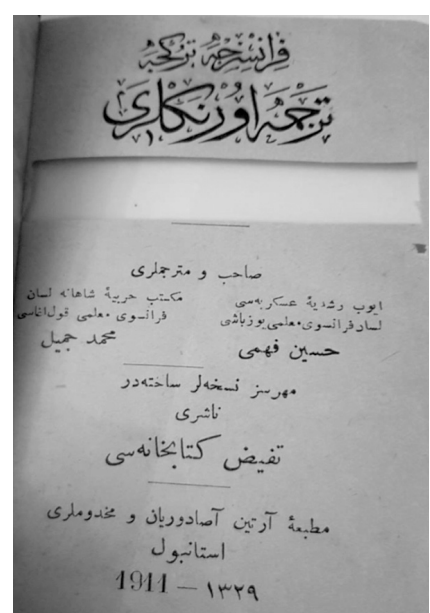


Ek 1: Çevriyazı

\begin{tabular}{|c|c|}
\hline \multicolumn{2}{|c|}{ Türkçe Fransızca } \\
\hline \multicolumn{2}{|c|}{ Tercüme örnekleri } \\
\hline \multicolumn{2}{|c|}{ Modèles de Traduction } \\
\hline \multicolumn{2}{|c|}{ TURC-FRANÇAİS } \\
\hline \multicolumn{2}{|c|}{ Eser } \\
\hline Mektebi Harbiye-i Şahane & Eyüb Rüştiye-i Askeriyyesi \\
\hline Lisan-1 Fransevi Muallimi Kolağası & Lisan-1 Fransevi Muallimi Yüzbaşı \\
\hline Mehmet Cemil & Hüseyin Fehmi \\
\hline \multicolumn{2}{|c|}{ Sahib ve Neşri } \\
\hline \multicolumn{2}{|c|}{ Tefeyuz Kitabhanesi } \\
\hline \multicolumn{2}{|c|}{ Matbay-1 Artin Asdoryan ve mahdumları } \\
\hline \multicolumn{2}{|c|}{ İstanbul } \\
\hline \multicolumn{2}{|c|}{$1911-1329$} \\
\hline
\end{tabular}

Ek 2: Çevriyazı

\begin{tabular}{|c|c|}
\hline \multicolumn{2}{|c|}{ Fransızca Türkçe } \\
\hline \multicolumn{2}{|c|}{ Tercüme örnekleri } \\
\hline \multicolumn{2}{|c|}{$\begin{array}{c}\text { Fançais-Turc } \\
\text { Modèles de Traduction } \\
\text { (Sayfa Kesilip Kitap Sırtına Yapıştırılmış) }\end{array}$} \\
\hline \multicolumn{2}{|c|}{ Sahib ve mütercimleri } \\
\hline Mektebi Harbiye-i Şahane & Eyüb Rüştiye-i Askeriyyesi \\
\hline Lisan-1 Fransevi Muallimi Kolağası & Lisan-1 Fransevi Muallimi Yüzbaş1 \\
\hline Mehmet Cemil & Hüseyin Fehmi \\
\hline \multicolumn{2}{|c|}{ Mühürsüz nüshalar sahtedir } \\
\hline \multicolumn{2}{|c|}{ Neşri } \\
\hline \multicolumn{2}{|c|}{ Tefeyuz Kitabhanesi } \\
\hline \multicolumn{2}{|c|}{ Matbay-1 Artin Asdoryan ve mahdumları } \\
\hline & 329 \\
\hline
\end{tabular}


Ek 3: Yansıtmalı Çeviri

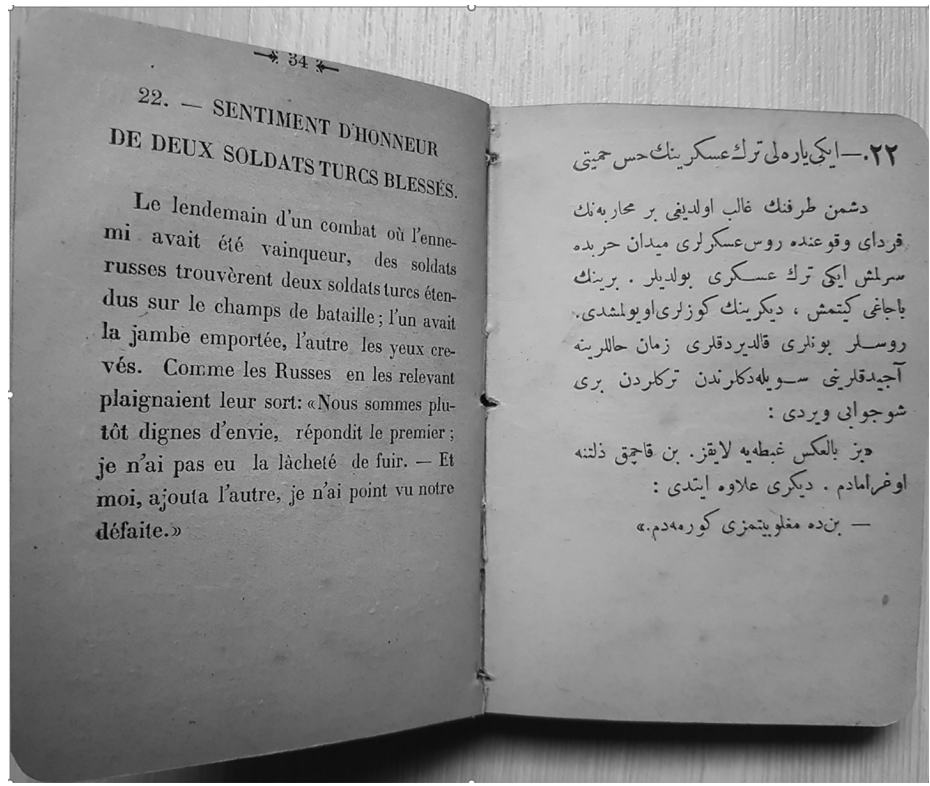

